\title{
Un nuevo inédito proconverso en el contexto de la rebelión toledana de 1449 . El códice 14 de la Catedral de Oviedo*
}

\author{
Valeria Lehmann** \\ Scuola Normale Superiore di Pisa \\ ORCID ID: https://orcid.org/0000-0001-9081-8444 \\ Pedro Martín Baños*** \\ Universidad Autónoma de Barcelona \\ ORCID ID: https://orcid.org/0000-0002-0439-9499
}

Se ofrece en este artículo la edición y traducción de un texto inédito anónimo en defensa de los conversos, escrito al calor de la revuelta toledana de 1449 por algún clérigo burgalés -de acuerdo con nuestras conjeturas- cercano al obispo Alonso de Cartagena. De igual manera que otros textos coetáneos (el Defensorium de Alonso de Cartagena, en efecto, la Instrucción del Relator de Fernán Díaz de Toledo o el Tratado contra los madianitas e israelitas de Juan de Torquemada), nuestro texto busca refutar con argumentos teológico-jurídicos las razones anticonversas, pero su peculiaridad distintiva es la de dirigirse directamente a los propios conversos en un tono de hondo patetismo: se trata de una suerte de consolatio pro conversis frente a las acusaciones y persecuciones de los cristianos viejos. El inédito forma parte de un códice de la Librería Gótica de la Catedral de Oviedo, de cuyos contenidos se ofrece una descripción exhaustiva.

Palabras Clave: Conversos; rebelión de 1449; antisemitismo; Alonso de Cartagena; Catedral de Oviedo.

* Este artículo se inscribe en el marco de los proyectos del Ministerio de Ciencia, Innovación y Universidades Alfonso de Cartagena. Obras Completas (FFI 2014-55902-P y FFI 2017-84858-P, IEMYRhd y Universidad de Salamanca) y Los límites del disenso. La política expurgatoria de la Monarquía hispánica (1571-1584) (PGC2018-096610, Universidad Autónoma de Barcelona). Quede constancia aquí de nuestro agradecimiento al archivero de la Catedral, don Agustín Hevia Ballina, y al grupo DigiCodex de la Universidad de Oviedo, constituido por los profesores Raquel Sáenz Pascual, Pedro Manuel Suárez-Martínez y Pedro Álvarez Cifuentes. Gracias a ellos pudimos inspeccionar el códice in situ, y hemos dispuesto de reproducciones de excelente calidad para su estudio.

** valeria.lehmann@sns.it

*** pmartinbanos@yahoo.es

Copyright: (C) 2021 CSIC. Este es un artículo de acceso abierto distribuido bajo los términos de la licencia de uso y distribución Creative Commons Reconocimiento 4.0 Internacional (CC BY 4.0). 
A New Unpublished Proconverso Text in the Context of the Toledo Revolt of 1449. The Codex 14 of the Oviedo Cathedral.- This article provides the edition and translation of an anonymous unpublished text in defense of the converts, written after the Toledo revolt of 1449. The author is conjectured to be some clergyman from Burgos, close to bishop Alonso de Cartagena. In the same way as other contemporary works (those by Alonso de Cartagena, indeed, Fernán Díaz de Toledo, or Juan de Torquemada), our text seeks to refute the anti-converso reasons with theological-juridical arguments, but it also addresses directly to the converts themselves in a tone of deep pathos: it is a kind of consolatio pro conversis against the accusations and prosecutions of old christians. The text is part of a manuscript of the Gothic Library of the Cathedral of Oviedo, whose contents are thoroughly described.

KeYwords: Converts; 1449 Rebellion; Antisemitism; Alonso de Cartagena; Cathedral of Oviedo.

\section{El códice 14 de la Librería Gótica de la Catedral de Oviedo}

El inédito que damos a conocer en este artículo se ha conservado en el códice 14 de la Librería Gótica de la Catedral de Oviedo, una miscelánea manuscrita de la que se ha publicado ya un par de piezas, pero de la que no existe todavía una adecuada descripción ${ }^{1}$. El primer editor de una de estas piezas, un sermón anónimo proconverso que el rey don Juan II encargó en 1449, advirtió ya la existencia del texto que aquí presentamos -contiguo al sermón en el manuscrito-y, catalogándolo imprecisamente como «una respuesta anónima a una serie de preguntas formuladas por judíos conversos», prometió ocuparse de él «no tardando» (algo que no cumplió, que sepamos) ${ }^{2}$; los editores más recientes de ese

${ }^{1}$ Las descripciones anteriores del códice son muy provisionales: Antonio SIERRA Corella «Ligeras noticias sobre el Archivo y la Librería Gótica de la Catedral de Oviedo», Revista de Archivos, Bibliotecas y Museos 34 (1930) págs. 123-140: 130; Alfonso ANDRÉs ToBAR, «Notas para un catálogo de códices de la catedral ovetense», Memorial Histórico Español 50 (1963) págs. 241-328: 266-269 (catalogado como códice 15, de acuerdo con la antigua numeración), y Bernardo Alonso RodríguEz, Juan Alfonso de Benavente, canonista salmantino del siglo XV (Roma-Madrid: CSIC, 1964) págs. 82-84. Nuestra gratitud, asimismo, a Juan Miguel Valero, de la Universidad de Salamanca; y a Teresa Jiménez Calvente, de la Universidad de Alcalá, que ha revisado el texto latino y ha mejorado la edición con sus finas sugerencias.

2 Joaquín BlázQueZ, «Sermón anónimo pro judíos conversos», Revista Española de Teología 34 (1974) págs. 257-274: 258. 
mismo sermón, por su parte, que no vieron el volumen completo (manejaron tan solo una reproducción de los folios de su interés), desatendieron también el texto que nos ocupa, pese a que a buen seguro habría aprovechado a su investigación ${ }^{3}$.

Será bueno comenzar, por tanto, por un inventario detallado de los contenidos del códice 14, que nos permitirá arriesgar más adelante alguna hipótesis sobre fecha y autoría, y que en cualquier caso esperamos pueda beneficiar en el futuro a otros estudiosos. El inédito de nuestro interés hace el número [6].

Oviedo, Librería Gótica de la Catedral, Cod. 14

Manuscrito del siglo xv. 215 fols. (los fols. 1r-3v, 85v-87v, 116vb-119vb y 215v en blanco). Consta de dos partes de distinta factura: I) los folios 1-119, con al menos dos copistas; y II) los folios 120-215, con una tercera mano. Escrito a dos columnas, en letra gótica minúscula. La primera parte del códice posee numeración romana en la parte inferior derecha del recto de los folios. La segunda parte utiliza reclamos. En el tejuelo del lomo: Repetit. Ioan. Alphons. de Benavent. En el recto de la hoja de guarda: Repetitiones Io. Alfonso de Benavente doctoris et alia opera. Encuadernación en madera cubierta de piel, con arabescos y cuatro broches metálicos.

[1] fols. 4r-85r. [Alonso Fernández de Madrigal, el Tostado, Libro en RESPUESTA DE CUATRO CUESTIONES].

inc. Muy virtuoso e muy discreto señor el maestre scuela de Salamanca, me encomiendo en vuestra merçed, de la qual reçebí una letra...

expl. ...si en algo pareciere defecto o error, el letor perdone corigendo lo con karidad, la qual a todas las buenas cosas mueve. (En otra tinta:) Domynus dixid [sic] ad me.

De fecha incierta, la obra fue editada en 1507 por Juan Gysser: Julián Martín ABAD, Post-incunables ibéricos (Madrid: Ollero \& Ramos, 20012016), n. ${ }^{\circ}$ 1478; Philobiblon [http://bancroft.berkeley.edu/philobiblon/ search_en.html; consultado en 20 de enero de 2020] BETA texid 2812. Existe al menos otro manuscrito en Madrid, Casa de Alba, ms. 100 (cf. Gema Avenoza «Las traducciones de la Biblia en castellano en la Edad Media y sus comentarios», en La Biblia en la literatura española, coord. Gregorio del Olmo Lete (Madrid: Trotta, 2008), vol. 1.2, págs. 59-60,

3 Tomás González Rolán y Pilar Saquero Suárez-Somonte, De la 'Sentencia-Estatuto' de Pero Sarmiento a la 'Instrucción' del Relator (Madrid: Abez Ezra, 2012) págs. 33-77. 
quien lo considera anónimo). Véase además Juan Miguel Valero MoRENO «Antecedentes y encrucijadas de la vida activa y contemplativa en la Castilla del Cuatrocientos», eHumanista 29 (2015) págs. 32-71: 54-55.

[2] fols. 88ra-98rb. Juan Alfonso de Benavente, Repetición De Restitutione MOLE ABLATORUM (I).

inc. Florentes patres et prudentissimi domyni. Quia principale propositum est animas...

expl. ...in litteris de raptor, in fine. Que bene nota. Istam repeticionem de restitucionem male [sic] ablatorum composuit et fecit Iohanes Alphonsi de Benavento, Decretorum doctor, quatedram Decreti hore vesperorum in studio Salamantini actu regens. Anno Domini 1449.

Cf. Alonso Rodríguez, Juan Alfonso de Benavente, págs. 126-133 (con estudio y edición parcial, sobre la base de otro manuscrito).

[3] fols. 98va-109vb. Juan Alfonso de Benavente, repetición In C. Qui in VIVORUM DE CONCESSIONE PRAEBENDAE ET ECCLESIAE NON VACANTIS. (X 3.8.1).

inc. Heroici viri et patres dignissimi, quia ut dicit Séneca, libro $2^{\circ}$ De clemencia, ex cupidine alieni omen malum...

expl. ...in istis casibus verificatur conclusio, secus in aliis casibus supra notatis. Istam repeticionem fecit Iohanes Alfonsi de Benavento, Decretorum doctor, unam de cathedris prime in Salamantino studio actu regens, die sancti Michaelis, octava die madii. Anno Domini 1451. Deo gracias.

Cf. Alonso Rodríguez, Juan Alfonso de Benavente, págs. 133-138 (con estudio y edición parcial, sobre la base de otro manuscrito).

[4] fols. 110ra-116va. Juan Alfonso de Benavente, fragmento de la REPETICIÓN DE RESTITUTIONE MOLE ABLATORUM (II).

inc. In articulo mortis volens et non potens vatizari $[\mathrm{sic}]$ pro batizato habetur si statim moreretur sed si supervixerit...

expl. ...me Papa dispensare potest, nec cum eius dispensacione aliquis in foro consciencie est tutus.

Cf. Alonso Rodríguez, Juan Alfonso de Benavente, págs. 168-171 (con estudio y edición parcial sobre la base de otro manuscrito). La repetición, segunda de su autor sobre el mismo tema, fue compuesta en 1458.

[5] fols. 120ra-127vb. [ANÓnimo], DE MANDATO REGIE MAIESTATIS SERMO IN DIE BEATI Augustini. Thema: Solliciti servare unitatem spiritus in vinculo pacis. Eph. $4[$ Eph. 4,3]. 
inc. Pridie, illustrissime princeps ac potentissime rex, in alio sermone per me astante vestra celsitudine regia facto...

expl. ...quam nobis omnibus prestare dignetur ipse Dei Filius qui cum Deo et Spiritu Sancto vivit et regnat per infinita secula seculorem. Amen.

[Al final:] Propositiones heretice, quarum heresiarcha Marquilius et conplices sui sunt assertores. Sunt que sequuntur.

inc. Prima. Quod regi veniene in suam civitatem licitum fuit ei porta[m] claudere.

expl. ...quia repellendus a testimonio et ab actibus legitimis, etc.

Editado por BlÁzQuEZ, «Sermón anónimo» y por GonzÁlez RoláN y Saquero SuÁrez-Somonte, De la 'Sentencia-Estatuto' de Pero Sarmiento, págs. 33-77 (con traducción castellana). El sermón, contra la discriminación de los conversos, fue pronunciado el 28 de agosto de 1449 en presencia del rey don Juan II, parece obvio que en Valladolid, donde paraba la corte. El autor alude a otro sermón sobre los desórdenes y guerras en el reino, pronunciado, también ante el rey, el día anterior.

[6] fols. 128ra-135rb. [ANÓNIMO, CONSOLATIO PRO CONVERSIS].

inc. Queritis, fratres in Christo karissimi, quid sibi vult istud novum genus belli.

expl. ...id ipsum sapere, conteratque Sathanam vestris velociter. Gracia Domini nostri Ihesu Christi vobiscum. Amen.

[Al final:] Conclusiones vel sentencie que ad laudem et gloriam Domini nostri Ihesu Christi eiusque beatissime matris Virginis Marie consolacionemque vestram et adversariorum confutacionem ex predictis possunt elici correlarie vel incidenter. Sunt que secuntur.

inc. Prima conclusio. Dicere quod Christus dominus noster et beatissima eius mater Virgo Maria non fuerunt de genere Iudeorum est hereticum...

expl. ...iniquos homines et blasphemos procedere et illos condigna animadversione punire, quod si non faciant mortaliter peccant.

[7] fols. 135va-139rb. [ANÓnIMO], SERMO IN DIE CENE. Thema: Omnis igitur cultura Domini rite conpleta est in die illa. $2 .^{\circ}$ Par. $25 .^{\circ}$ c. ${ }^{\circ}$ (2 Par. 35,16).

inc. Iudeorum populus audiens Salvatoris nostri et domini Ihesu Christi doctrinam saluberrimam...

expl. ...qui cum Patre et Spiritu Sancto vivit et regnat, per infinita secula seculorum benedictus. Amen. 
[8] 139va-164ra. Juan Alfonso de Benavente, Ars et Doctrina studendi et DOCENDI.

inc. In nomine Domini nostri Iesu Christi Salvatoris nostri, in quo est omnis ratio superne scientie vel terrene creature...

expl. Explicit ars et doctrina studendi et docendi composita per me, Ioannem Alfonsum de Benavento, Decretorum doctorem et in artibus bachallarium, unam de cathedris canonum prime in studio Salamantino actu regentem; quam ad Dei servitium et omnium studentium profectum, in mensibus Iulii et Augusti, auxiliante Deo, composui anno Domini millesimo quatuorcentesimo quinquagesimo tertio (1453). Laus et honor et gloria sit Deo. Amen.

Editado íntegramente en Juan Alfonso de Benavente, Ars et doctrina studendi et docendi, edición crítica y estudio por Bernardo Alonso RoDRÍGUEZ (Salamanca: Universidad Pontificia, 1972).

[9] fols. 164-179rb. [ANÓNIMO], RESPONSIO APOLOGITICA AD EPISTOLAM FRATRIS AlFonsi de Zamora CATHOLICO REGI DOMINO NOSTRO MISSAM.

inc. Sepiu[s] et sepius, conpatriota frater Alfonse, insolencias tuas audiens amicabiliter respondebam...

expl. ...vobis in patrem et vos eritis michi in filios, dicit Dominus omnipotens, cuius gloria in Ecclesia et in Christo Ihesu per infinita secula seculorum.

Editado en Pedro Martín Baños, La herejía de Durango y la inédita "Responsio apologitica ad epistolam fratris Alfonsi de Zamora» (c. 1441) (Salamanca: Semyr, 2021). En 1441 o 1442, el franciscano fray Alfonso de Mella, hermano del obispo de Zamora y principal sostenedor de la conocida como herejía de Durango, enviaba al monarca castellano una carta que justificaba sus postulados teológicos y su huida al reino de Granada: $c f$. también Iñaki BAzÁn DíAz, Los herejes de Durango y la búsqueda de la Edad del Espíritu Santo en el siglo XV (Durango: Museo de Arte e Historia de Durango, 2007), págs. 243257. Este ítem [9] es una respuesta, inédita y desconocida, a esa carta, compuesta por un 'compatriota' que refuta ampliamente el escrito de fray Alfonso, después de, tal y como confiesa, haber defendido previamente las insolencias del franciscano como propias de un temperamento excesivamente fervoroso; la lectura de la carta, sin embargo, desencanta definitivamente al anónimo 'compatriota' y le lleva a tomar la pluma para combatir al hereje. 
[10] fols. 179ra-180va. [ANóNimo, Epístola al papa Nicolás V].

inc. Cretiscit [sic por Crescit] Ecclesie gaudium, beatissime pater, defficiuntque in ea querela et clamor in assu[m]pcione vestre sanctitatis ad summi appostolatus apicem..

expl. ...et gloriam illius qui illam novis docendam et gubernandam comisit cuius est potestas et inperium per infinita seculorum secula. Amen.

El autor de la epístola (desprovista de salutatio) se dirige a un recién elegido Nicolás $\mathrm{V}$, a quien adjunta el sermón que se corresponde con el ítem [11] (o cuando menos una reportatio del mismo), sobre el que ofrece las siguientes explicaciones: fue el rey castellano (don Juan II) quien se lo encomendó a él, un indigno capellán suyo; la prédica resultante se pronunció en Burgos en presencia del rey y del obispo de la ciudad (Alfonso de Cartagena). Nicolás V fue nombrado papa en marzo de 1447, pero la fecha de la carta y del sermón ha de retrasarse seguramente hasta junio o septiembre de 1448 (meses en que la corte estuvo en la ciudad burgalesa) ${ }^{4}$.

[11] fols. 180va-185ra. [Anónimo, Sermo. Thema:] Ad ipsum dicatis omnis et non sint in vobis cismata. Prima Cor. primo. [1 Cor. 1,10].

inc. [Co]nversi ad fidem Christi per predicacionem apostoli Pauli, cum essent inicio pauci homines indocti, pauperes et inpotentes ex diversis nacionibus et oppinionibus, puta ex Iudeis et gentilibus congregati...

4 «Sed re vera, beatissime pater, divina gracia, ut credo, cordi regio instillante, melius mecum actum est: dedit enim in mandatis sua celsitudo michi, indigno capellano suo, quod de grata devotaque obediencia a se per solempnem anbaxiatorem suum santitati vestre tam reverenter tamquam humiliter collata in presencia sue magestatis sermonem ad curiam et populum facerem, ipsamque in illis et per illos omnibus regnis et dominis suis publice predicarem; unde omnes regnicolas et subditos suos tam magnos quam parvos utriusque status, tam ecclesiastica quam secularis, admonuerit precepit, quod si indignacionem suam incurrere metuebant, romanum pontificem Nicholaum quintum ut vicarium Christi, successorem Petri devote colerent, illumque pro vero et indubitato Papa tenerent, illique tanquam omnium christianorum patri, ut ipse obedierat, pure et simpliciter obedirent. O princeps ecclesie, o mundi lampas, sanctitati vestre animo trepidanti signiffico quod huius regalis mandati seriem tam seleriter [sic] excequi [sic] volui, quod, deffectum sciencie facundieque oblitus, cathedram indubitanter ascendi et in potestate [?] regie magestatis presencia in illa famosa ecclesia Burgensi celebrante, eiusdem ecclesie episcopo astante, prelatorum et baronum aliorumque nobilium et popularium multitudine copiosa, non defficiente illo qui dat verbum evangelizantibus in virtute multa [Ps. 67.12] et sermonem qui sequitur feci. Cuius sentencias etsi non verba omnia literis demandavi illasque sub parvo et rudi epilogo sanctitati vestre videndas transumpsi» (fols. 180r-ab). 
expl. ...dignetur ille Dei Filius qui cum Patre et Spiritu Sancto vivit et regnat, per in secula seculorum benedictus. Amen.

El sermón desarrolla con profusión de argumentos la necesidad de evitar los cismas, comparando la Iglesia con otras formas de organización social (domus, civitas, regnum); la conclusión es que, en todas las instituciones, la estabilidad se alcanza invariablemente a través de la obediencia. En el propio sermón se hace referencia a las circunstancias explicadas en el ítem [10]: el nombramiento reciente del cardenal Tommaso Parentuccelli de Sarzana (Thomas de Cerezana) como Nicolás V, y el acatamiento sin reservas de don Juan II, que, se asegura, ya había apostado decididamente por la unidad de la Iglesia en las embajadas enviadas a los concilios de Constanza y Basilea ${ }^{5}$.

[12] fols. 185ra-188va. [ANÓNIMO, EPÍSTOLA SOBRE LAS EXCELENCIAS DE LA VIDA RELIGIOSA].

inscriptio: Devotis religiosisque dominabus, sororibus in Christo michi dilectis, priorisse conventuique canonicarum monasterii Sancte Marie la Blanca in Burgensi nobilissima civitate.

inc. Cum meditarer, sorores in Christo dilectissime, caritati vestre absens scribens quod presens olim adortatus fueram, scilicet excellenciam status religionis, permaxime in sacro ordine nostro canonico, ad quem cum expeditas et habiles cernerem conscendere vos desiderabam...

5 «Nichilominus [illustrisimus dominus noster rex] semper anteposuit de pace universalis Ecclesie cogitare, illam totis viribus procurare, in eius tractatus magnos sumptus exponere. Patet de solepmnibus anbaxiatis quas ad consilia Constaciense et Basiliense magnifice transmisit, in quorum primo cum magna sue celsitudinis vigilancia vetus cisma fuit radicitus extirpatum, in secundo ebulienti cismati non concessit, sed unitati Romane Ecclesie eiusque vero pastori costanter adhesit. [...] Demum, illo beatissimo papa Eugenio nuper miseracione divina presenti vita functo, ad electionem futuri sumi ponfifficis per illos qui possunt et debent ut sacri canones iubent congruis loco et tempore processum est. Electus est concorditer unus de cardinalibus nomen dopmnus Thomas de Cerezana, vir etatis provecte eloquencia clarus, sapiencia eminens sanctissime theologie eximius, professor sanctitate non infimus [...], cuius nomine baptismali, ut in similibus electionibus vel assumptionibus solicitum est fieri imitacione dextere Excelsi mutato, vocatus est Nicholaus Papa quintus. [...] Cognito ergo per regiam celsitudinem quod electio de persona tante dignitatis et meriti fuerit rite et canonice celebrata, misit solempnem anbaxiatam sumi [?] qui nomine suo obedienciam et reverenciam illi ut vero et indubitato pape pure et simpliciter exiberet, quia vero $\mathrm{co}[\mathrm{n}] \mathrm{stat}$ prefate regie celsitudini quod iam fuerit decenter exibita et per prefatum suum pontifficem cum magno gaudio et solepmnitate recepta» (fols. 183rb-184vb). 
expl. ...dignetur ipse dei Filius qui cum Patre et Spiritu Sancto regnat, per infinita seculorum secula benedictus. Amen. Et virgo examen [?].

El autor de la carta, un clérigo anónimo, escribe a la prioresa y las hermanas del convento de Santa María la Blanca sobre un asunto, las excelencias de la vida religiosa, sobre el que ellas le rogaron en otro tiempo, de viva voz, que las instruyera. La congregación burgalesa de las monjas de Santa Dorotea vivió en el palacio adyacente a la iglesia de Santa María la Blanca desde 1424 hasta 1459, fechas que pueden enmarcar la redacción de la epístola: Domingo Hergueta y MARTín, Monografía sobre la imagen y templo de Nuestra Señora la Blanca de la Ciudad de Burgos (Lérida: Imprenta Mariana, 1922), págs. 23-24; Teófilo LóPez MATA «Convento de Santa Dorotea», Boletín de la Institución Fernán González 165 (1965) págs. 798-801.

[13] fols. 188va-193rb. [ANÓNIMO], IN DIE CENE SERMO. Thema: Rex fecit cenam magnam omnibus vernaculis suis et omnibus magistratibus. $3 .^{\circ}$ Esdre c. ${ }^{\circ}$ 14. [3 Esdr. 3,1].

inc. Salvator noster dominus Ihesus Christus cum a regalibus sedibus in hanc nostram peregrinacionem ut salvum faceret quod perierat descendisset volens nos sue salutis et redempcionis esse participes...

expl. Cuius ipse inperanti nos participes faciat ut ad cenam vite eterne per eius graciam pervenire valeamus. Quam nobis omnibus prestare dignetur. etc. etc.

Existe otro manuscrito que alberga el sermón: Burgo de Osma, Catedral, ms. 26, fols. 1r-4r: Pedro CÁTEDRA, Los sermones atribuidos a Pedro Marín; van añadidas algunas noticias sobre la predicación castellana de San Vicente Ferrer (Salamanca: Universidad de Salamanca, 1990), págs. 50 y 59-60. En esta copia de Burgo de Osma acompaña al manuscrito una nota -ajena al sermón- fechada en 1455, que bien puede funcionar como término ante quem de su composición. La prédica se pronunció ante un obispo y un cabildo indeterminados: quod fuit, reverendissime preside (praesul en el manuscrito de Burgo de Osma), thema preffatum vestre inclite paternitati ceteris patribus et dominis humiliter presentatum (Oviedo, cod. 14, fols. 188vb-189ra).

[14] fols. 193rb-195vb. [Anónimo], Sermo in CENA Domini. Thema: Rex Assuerus tertio anno inperii sui fecit grande convivium omnibus principibus suis et pueris suis fortissimis, invitavit omnem populum qui in Susis inventus est et septem diebus iussit convivium preparari in vestibulo orti et nemoris quod regio cultu et manu consitum erat. Hester c. ${ }^{\circ}$ primo [Esth. 1,3-5]. 
inc. Hec est celeberrima nox, illustrissime principum ac potentissime rex, in qua Deus deorum, Salvator Dominus noster Ihesus Christus, sacratissimam et ultimam cenam cum discipulis suis in carne passibili ante quam traderetur effecit...

expl. ...constat ita societas ecclesiastica ex multis personis a criminali macula liberis consistit in cuius rei tipo facta est archa Domini de lignis sethim que sunt inputribilia et albe spine similia [en el margen superior: Exo. 25].

Como puede observarse en el incipit, el sermón fue predicado ante el rey (también, en el fol. 193vb: Attenda ergo supplico, vestra regia celcitudo [sic], qualiter in hac sacratissima cena...).

[15] fols. 195vb-198ra. [Anónimo], Cermo [sic] in die Cene. Thema: Convenientibus vobis in unum iam non est dominicam cenam manducare. Prima Cor. 11 c. $^{0}$ [1 Cor. 11,20$]$.

inc. Dominus et Salvator noster Ihesus Christus volens genus humanum ad saluberrimum effectum sue benedicte passionis recipiendum...

expl. ... cui gracia yra est, calix propiciacionis calix indignacionis, aqua nos liberet ipse Dei Filius, qui cum Patre et Spiritu Sancto vivit et regnat per infinita secula benedictus. Amen.

Pronunciado asimismo ante un indeterminado rey: Opera vero virtuosa, attendat, regia magestas et intelligat... (fol. 196ra); quod fuit verbum preffactum vestre magniffice celcitudini [sic] humiliter presentatum... (fol. 196va); ad cuius verbi evidenciam, serenissime princeps, tria sunt... (fol. 196vb).

[16] fols. 198ra-201rb. [Anónimo], Sermo in CEna Domini. Thema: Rex Darius fecit cenam magnam omnibus vernaculis suis et omnibus magistratibus. $2^{\circ}$ Esaie c. ${ }^{\circ} 9$ [sic por 3 Esdr. 3,1].

inc. Moris est usitati et non inprobanda consuetudo cum quis longum iter est profecturus amicis et notis solempne convivium facit...

expl. Istud sacramentum fit ex rebus que ad unum aliquid rediguuntur, ut ex multis granis unus panis et ex multis racemis vinum confluit.

De nuevo predicado ante el rey: quod fuit thema prefactum vestre regie celsitudini humiliter presentatum (fol. 199ra).

[17] fols. 201va-204vb [ANÓnimo, SERMo] IN DIE CENE. Thema: Expurgate vetus fermentum ut sitis nova consparsio. Prima Cor. $5^{\circ}$ [1 Cor. 5,7].

inc. Dominus noster Ihesus Christus novus Adam novos filios generare volens non in novitate carnis, sed in novitate spiritus opera carnis per appostolum suum nos movet abicere et spiritualia anplecti... 
expl. ...quod sacramentum esset perfectum ab efficacia, quia corpus erat unitum divinitati, et perfectum a signifficancia, sed tamen non a continencia et racio huius est quia inperfectio erat in ipso significato, quia corpus erat mortuum. etc. etc.

También pronunciado ante el rey, con alusión a que una parte del sermón se pronunció en lengua vulgar: ...et hoc loquendo secundum sensum tropologicum quem in prima parte huius brevis collacionis sermone latino prossequar, licet ruditer et inepte, preffacti thematis sensum alegoricum pro secunda parte ut regia celssitudo iniunxit vulgari eloquio reservando (fol. 201va).

[18] fols. 205ra-207ra. [Anónimo], Sermo die sancti Thome D[e] Aquino. Thema: Ministerium tuum imple, sobrius esto. Secunda Thimoteum $\mathrm{c}^{\mathrm{o}} 10^{\circ}[2$ Tim. 4,5].

inc. Prefacti thematis due possunt esse intelligende: prima quod sint duo precepta ut sunt due oraciones; secunda quod principaliter unum sit preceptum, scilicet de impletione ministerii...

expl. ...missus sum ad te ut indicarem tibi doctrinam et gloriam fratris Thome. Hic mecum est in gloria, equalis michi est nisi quod virginitatis aureola me percellit et ego ipsum in pontifficali ordinis dignitate.

[19] fols. 207ra-209ra. [Anónimo, Sermo] in die Penthecoste. Thema: De excelso misit ignem in ossibus meis et erudivit me. Tre. $\mathrm{c}^{\mathrm{o}} \mathrm{p}^{\mathrm{o}}$ [Lam. 1,13].

inc. Christus Dominus noster profuit nobis vivens et salutem et vitam contulit moriens; vivens fuit noster doctor et legis lator...

expl. ...et quilibet nostrum in voce laudis et congratulacionis poterit dicere: 'Misit misit ignem in ossibus meis et erudivit me', quod fuit thema.

Al texto le sigue lo que parece una breve epístola, que transcribimos, dirigida a una dignidad religiosa, con mención de una intercesión ante el rey: Crebra aut longua [sic] scriptura, reverende pater et domine mi prestantissime, reverendam dominacionem animum atediare non vellem. Verum [vereum ms.] quia Salvator in Evangelio docet nos ad ianuam amici inportune pulsare [Lc. 11,8], suplicacionem pridie missam iterare decrevi, ut si forte parvitas mea non est merita optinere, saltem importunitas consequatur, et si hoc vel illud non sufficiat, indignitas mea suplico non causet regales preces suo fraudari intentu. Scio enim, circunspectissime domine, magestatem regiam illas dispensacione michi acomodas [?], pro quibus sanctitati Domini nostri affectuose suplicavit et reverende circumspectioni vestre mittit ob eadem sola obtineri et 
graciarum actione velle illi soli debere persolvi, reverendissime domine, misi que in partibus istis michi possibilia sunt, eidem et paternitati vestre grata suplico iniungite, laboribus enim vel expensis die noctuque non parcam. Valeat ut desiderat eadem vestra reverenda paternitas ad Dei et ecclesie sue honorem per tempora longiora.

[20] fols. 209rb-212va. [ANónimo], SERMo in FESTO PURIFFICACIONIS. Thema: Placebit Domino sacrifficium Iuda et Iherusalem sicut dies seculi et anni antiqui. Malachie $3 .^{\circ}$ c. ${ }^{\circ}$ [Mal. 3,4].

inc. Sancta mater Ecclesia hoc celebrat festum et facit solempnem conmemoracionem illius sacratissime oblacionis et benedicti sacrifficii...

expl. ...videre bona in pace eternitatis qui a gloriam quam nobis prestare dignetur qui in trinitate perfecta vivit et regnat per infinita secula seculorum. Amen.

[21] fols. 212va-215ra. [Anónimo], In FEsto sanCti THome De AQuino. Ihesus. Thema: Caritas non querit que sua sunt. Prima Cor. $13^{\circ}$ [1 Cor. 13,5].

inc. Totus sermo per per $[s i c]$ Dei graciam versabitur circa declaracionem thematis ubi suo veniunt declaranda: primum quod signifficetur nomine caritatis...

expl. ...quis bonus dubitet mortem appetam si ei sit profuturus ex quo est detestabilior istarum inmanitas que laceraverunt omni scelere patriam et mea funditus delenda occupati sunt et fuerunt.

\section{Fechas y autores. Algunas conjeturas}

El códice posee dos partes de hechuras materiales bien diferenciadas. Los ítems 1-4 remiten indefectiblemente a Salamanca: contienen una obra del Tostado, de fecha incierta (aunque seguramente enmarcable entre 1444 y 1456) ${ }^{6}$, y en otra mano tres lecciones magistrales (o repetitiones) del canonista y profesor de Salamanca Juan Alfonso de Benavente, fechadas explícitamente dos de ellas en 1449 y 1451 , respectivamente, en tanto que para la tercera, fragmentaria, hemos de aceptar la data de 1458 que figura en otro testimonio, esta vez completo, de la misma obra (véase, arriba, la descripción del manuscrito).

${ }^{6}$ La carta introductoria parece aludir al Tostado como maestrescuela de la universidad salmantina (cargo que este ejerció entre 1444 y 1456, en efecto). No obstante, véase VALERo Moreno «Antecedentes y encrucijadas de la vida activa», págs. 54-55. 
La segunda parte del códice coincide con la primera en que la obra número [8] es también de Juan Alfonso de Benavente (un Ars et doctrina studendi et docendi de 1453), pero el resto de los ítems constituye una colección de textos diversos consistentemente ofrecidos como anónimos. No es descartable que esta segunda parte del manuscrito sea de un taller de copia salmantino - como no lo es, a la inversa, que la primera parte fuese copiada en otro lado-, pero, salvo el [8], los textos congregados no parecen estar necesariamente emparentados con la ciudad del Tormes, y varios de ellos, de hecho, como vamos a comprobar, no lo están. La datación cierta de muchas de las piezas se mueve en un arco temporal de poco más de una década en torno a mitad de siglo: $c a$. 1441 (ítem [9]), 1448 (ítems [10] y [11]), 1449 (ítems [5] y [6]) y 1453 (ítem [8]) (los ítems [12-13] podrían perfectamente situarse en estas fechas, aunque sus términos ante quem son algo más tardíos: 1459 y 1455).

Extrapolando estos datos, y admitiendo que las dos partes del códice fueron muy probablemente reunidas a posteriori, la primera podría haber sido confeccionada poco después de 1458, mientras que la segunda en torno quizás a 1455 , si no antes.

Sobre la autoría de los textos anónimos es difícil pronunciarse, y lo único que podemos hacer es arañar del conjunto del manuscrito algunos pormenores que tal vez resulten relevantes. Hasta ahora, el único texto editado del ramillete de anónimos -el sermón proconverso del ítem [5]ha sido atribuido tanto a Juan de Torquemada como a Francisco Álvarez de Toledo, pero las conjeturas son, creemos, muy endebles, y sobre todo pecan de haber desatendido las eventuales relaciones del sermón con las demás obras que alberga el códice ovetense. Habiendo sido este sermón [5] predicado en Valladolid el 28 de agosto de 1449, ante el rey don Juan II, la candidatura del cardenal Torquemada, que paraba en Roma desde hacía una década larga, no parece de por sí demasiado sólida ${ }^{7}$. Del canónigo converso Francisco Álvarez de Toledo, que llegaría más tarde a

7 Véase Carlos del Valle Rodríguez, «En los orígenes del problema converso», en Tratado contra los madianitas e ismaelitas de Juan de Torquemada, eds. Eloy BeNITO Ruano y Carlos del Valle Rodríguez (Madrid: Aben Ezra, 2002) págs. 29-74: 67-68. Del Valle Rodríguez atribuye el sermón a Torquemada sobre dos bases muy débiles: para él, el sermón es una «disquisición teológica sobre la unidad de la Iglesia», «muy adecuada al cardenal Torquemada»; y tanto el sermón como el Tratado contra los madianitas de Torquemada utilizan una frase casi idéntica (velut cancer serpit / ut cancer 
ser obispo de Coria -y destinatario de una de las letras más extensas de Fernando de Pulgar-, se ha recordado que, huido de Toledo a raíz de la publicación de la Sentencia-Estatuto de Pero Sarmiento, redactó en primera instancia una impugnación urgente de la misma en siete proposiciones (desde el pueblo cercano de Santa Olalla), y que con más reposo compuso luego un Apologético de mayor aliento y extensión, enviado al obispo Lope de Barrientos, para finalmente recalar en Roma y asesorar a Torquemada en la intervención de este ante la curia pontificia. No obstante, la propia atribución de esta secuencia de hechos a Francisco de Toledo es problemática (se ha sugerido también el nombre de su pariente García Álvarez de Toledo), y ninguno de los dos textos aludidos se ha conservado: salvo por la militancia en el bando proconverso, no encontramos datos objetivos que vinculen las personas o las obras de estos Álvarez de Toledo con la prédica del sermón de finales de agosto de $1449^{8}$. Es muy llamativo, ciertamente, que el texto que aquí editamos venga rematado por siete conclusiones vel sentencie, pero tampoco este único apunte nos parece determinante si, a lo que parece, el escrito de Francisco (o García) de Toledo era una refutación explícita de la Sentencia-Estatuto ${ }^{9}$.

serpit), que omite aclararse que procede del Nuevo Testamento (2 Tim. 2,17), y que es documentable de forma profusa en la patrística y a lo largo de toda la Edad Media.

${ }^{8}$ La hipótesis de que el sermón sea de Francisco de Toledo se halla en GonZÁLEZ Rolán y Saquero Suárez-Somonte, De la 'Sentencia-Estatuto'de Pero Sarmiento, págs. 33-34. En su Historia eclesiástica de la imperial ciudad de Toledo, Jerónimo Román de la Higuera adjudicaba a García Álvarez de Toledo una cadena de acontecimientos semejante: la huida de Toledo, la redacción de un Apologético contra Sarmiento (en Santa Olalla) y la búsqueda de apoyos en Roma al amparo de Torquemada; $c f$. Benzion NeTANYAHU, Los orígenes de la Inquisición en la España del siglo XV (Barcelona: Crítica, 1999 ) pág. 1115, n. 12. Es Juan de Mariana, sin embargo, quien identifica al personaje con Francisco de Toledo, aunque silenciando su nombre y mezclando confusamente en la descripción del Apologético datos que se cohonestan mejor con la Instrucción del Relator, también enderezada a Lope de Barrientos; véase Eloy Benito Ruano, Los orígenes del problema converso (Madrid: Real Academia de la Historia, 2001) pág. 53. Sea como fuere, la cronología no ayuda demasiado para considerar como autor del sermón a alguno de estos Álvarez de Toledo, habida cuenta de que la primera bula de Nicolás $\mathrm{V}$ en contra de los sublevados toledanos - bula tras la que estaría Torquemada- fue promulgada el 24 de septiembre de 1449 .

${ }_{9}$ El detalle de las siete proposiciones, por otro lado, solo aparece en Mariana, no en Román de la Higuera. 
Analicemos ahora los pormenores, ciertamente escasos, pero enormemente significativos, que nos brinda el propio códice 14. Los ítems [10] y [11] se encuentran vinculados con Burgos. Cuando se produjo la elección de Nicolás V, en 1447, el rey castellano don Juan II envió de forma inmediata una embajada para prestar obediencia al nuevo papa, quien, pese a que no encontraría demasiadas resistencias para consolidarse en el solio vaticano, rivalizaba aún con el antipapa Félix V. Decidido a hacer frente a los rescoldos del conciliarismo en suelo hispano, don Juan quiso que Castilla acatase sin fisuras al pontífice y, además de la embajada, encargó la prédica de un sermón ad hoc que hiciese pública por todo el reino, de forma categórica, la posición real frente a Roma ${ }^{10}$. El sermón -el ítem [11], un ataque contra los cismas en la Iglesia- fue pronunciado por primera vez en Burgos, con la presencia del rey y del obispo de la ciudad, Alfonso de Cartagena (todo apunta a que en junio o septiembre de 1448) ${ }^{11}$. Por su parte, el anónimo capellán regio a quien se encomendó el sermón hizo copiar una reportatio del mismo para enviarla, junto con una breve misiva -el ítem [10], la fuente que nos entera de todo lo anterior: véase, arriba, la descripción del códice- al flamante papa Nicolás V. No parece descabellado, pues, suponer que [10] y [11] hubiesen sido compuestos por algún canónigo de Burgos que se movía, como capellán y predicador, en el entorno de la corte, y que probablemente perteneciese al círculo de colaboradores o protegidos del obispo Cartagena. Repasando la prosoprografía de la corte castellana de don Juan II, se nos ocurre que un candidato idóneo podría ser Luis González de Llanos, canónigo de León y Burgos, documentado como escribano de cámara y secretario de latín del rey desde 1433, acompañante de Alfonso de Cartagena en el concilio de Basilea (entre 1437 y

${ }^{10}$ Sobre las relaciones de don Juan II con el papado, véase Óscar Villarroel González, El rey y el papa. Política y diplomacia en los albores del Renacimiento (Castilla en el siglo XV) (Madrid: Sílex, 2009), quien lamentablemente no ofrece datos sobre esta embajada de obediencia de 1447 (el autor deplora, de hecho, la ausencia de noticias sobre las embajadas al papa durante los últimos diez años del reinado de don Juan II: pág. 276).

11 Don Juan II estuvo en Burgos en esos meses de 1448 (su estancia anterior se remonta a 1445 , y no volvió hasta 1451 , fecha demasiado alejada ya de la elección de Nicolás V); cf. Francisco de Paula Cañas Gálvez, El itinerario de la corte de Juan II de Castilla (1418-1454) (Madrid: Sílex, 2007). 
1438), y vinculado estrechamente a la catedral burgalesa (como capiscol y capellán mayor de la Visitación), y también a su obispo hasta la muerte de este en $1456^{12}$. No obstante, cabría explorar otras posibilidades en el círculo de familiares y protegidos de Cartagena (Diego Rodríguez de Almela, Juan Manrique o Alfonso García de Fuentes, por ejemplo) ${ }^{13}$.

La carta a las monjas de Santa Dorotea de Burgos -ítem [12]-, que habitaron un palacio contiguo a Santa María la Blanca hasta 1459, apunta igualmente hacia un religioso con ascendencia en la ciudad, que se reúne con las hermanas y que promete escribirles algo que mitigue los rigores de la vida monástica y las ayude a perseverar en su vocación: «aliquid quod vos consoletur, delectet, confortet, admoneat, in vestroque sancto proposito stabiliat» (fol. 185va). Habida cuenta de que, desde sus inicios, el convento de Santa Dorotea fue patrocinado, protegido y promovido ante el rey por Alfonso de Cartagena, la figura de un canónigo del entorno cultural del obispo -sea Luis González de Llanos u otro- nos parece de nuevo compatible con la autoría de la epístola.

Antes de regresar al sermón proconverso [5] y a nuestra pieza [6], retengamos asimismo los datos siguientes: los sermones [15], [16] y [17] fueron pronunciados ante el rey (que, si se atiende a la datación propuesta para la segunda parte del códice, debía de ser el mismo don Juan II); el sermón [13] se predicó ante un obispo y su cabildo; el [19] se remata con una breve nota de la que parece desprenderse -en un latín

12 Véase su semblanza en Francisco de Paula CAÑas GálVez, Burocracia y cancillería en la corte de Juan II de Castilla (1406-1454). Estudio institucional y prosopográfico (Salamanca: Ediciones Universidad de Salamanca, 2012) págs. 193-194 y 374-375. El archivo de la catedral de Burgos, que tiene digitalizada y brinda en línea buena parte de su documentación, permite localizar fácilmente decenas de documentos sobre González de Llanos entre 1435 y 1466, fecha de la muerte de este canónigo [<https:// www.fundacioncajacirculo.es/AHCB.php>]. Véase también Vicente Beltrán DE Her DIA, Cartulario de la Universidad de Salamanca (1218-1600) (Salamanca: Universidad, 1970) vol. I, págs. 450-452.

13 Cf. Luciano Serrano, Los conversos D. Pablo de Santa María y D. Alfonso de Cartagena, obispos de Burgos, gobernantes, diplomáticos y escritores (Madrid: Escuela de Estudios Hebraicos, 1942) págs. 258-260. García de Fuentes anduvo en Roma en 1452-1453, comisionado por el obispo de Burgos, y escribió desde allí una Coronación de la corona argéntea et áurea del emperador Sigismundo (BNE, Res. 35, fols. 76r-78v; ed. Antonio Paz y Melia, «Matrimonio y coronación del emperador Federico III», Revista de archivos, bibliotecas y museos VII:11 [noviembre de 1903] págs. 376-385). 
endiablado- que el autor de la pieza solicita al obispo que continúe intercediendo en su favor en la corte; y, finalmente, la Responsio apologitica al hereje Alfonso de Mella [9] la hace alguien que tiene acceso casi inmediato a la carta que el franciscano había hecho llegar al monarca de Castilla ${ }^{14}$.

Es obvio que todos los inéditos anónimos del códice no tendrían por qué pertenecer a una única pluma, pero los indicios acopiados sí permiten sospechar, a nuestro juicio, que al menos una parte de ellos puede atribuirse a un clérigo con contactos en el entorno regio y próximo al círculo de Alfonso de Cartagena. Si nos fijamos ya en los ítems [5] y [6], nuestra suposición cobra más fuerza aún: en el sermón [5], encargado por el rey y pronunciado ante él, se alude a otro sermón previo, predicado el día anterior, sobre «esos desórdenes, perturbaciones y guerras que se propagan hoy en día por toda la cristiandad y sobre todo por vuestro reino»; y tanto el sermón [5] como la pieza [6] que ahora nos ocupa, y que analizaremos con mayor detalle en los apartados siguientes, se muestran en absoluta sintonía con el argumentario jurídico-teológico con que se guarnecía desde la corte la protección a los conversos, y muy especialmente con el Defensorium unitatis christianae de Alfonso de Cartagena.

\section{Forma, Contenido y contextos de la Consolatio pro conversis}

No será necesario extenderse aquí sobre la rebelión toledana de 1449 contra el rey don Juan II, de sobras conocida, en la que se promulgó una Sentencia-Estatuto que, con apoyatura en ambos derechos, civil y canónico, buscaba prohibir que «ningún confesso del linaje de los judíos no pudiese aver ni tener ningún ofiçio ni benefiçio en la dicha çibdad de Toledo» ${ }^{15}$. La reacción contra esta pretensión de imponer lo que de facto

14 Así se deduce de las palabras con que entregan al anónimo autor la carta de marras: «Ecce sacrilegas licteras quas domino nostro regi [legi $\mathrm{ms}$.] pridie inpudenter transunsit» (fol. 164va). Desconocemos dónde nació Luis González de Llanos, pero debería ser zamorano -el autor de la Responsio se presenta como compatriota de Mella- para que pudiéramos atribuirle la pieza. Sí era zamorano, en cambio, Alfonso García de la Fuente. La Responsio acaba de editarse en Pedro Martín Baños, La herejía de Durango.

15 González Rolán y Saquero Suárez-Somonte, De la 'Sentencia-Estatuto' de Pero Sarmiento, págs. 21-22. La bibliografía imprescindible sobre el tema pasa por los estu- 
era un estatuto de limpieza de sangre fue contundente, y produjo una abundante literatura a favor de los derechos y la igualdad de los conversos en el seno del cristianismo, a la que viene a sumarse ahora esta que, a falta de título, hemos querido denominar como Consolatio pro conversis.

Si se compara con otros textos similares de la misma época (el Defensorium unitatis christianae de Alfonso de Cartagena, el Tratado contra los madianitas e ismaelitas de Juan de Torquemada, las glosas al Fuero Real de Díaz de Montalvo, la Instrucción del Relator de Fernán Díaz de Toledo o los varios opúsculos de Lope de Barrientos), la particularidad del texto que aquí presentamos es sin duda el hecho de que se dirige directamente a un público converso desde una voz igualmente conversa, mientras que aquellos otros, en cambio, tienen como destinatario preferente a las autoridades que tenían que defender a los cristianos nuevos desde sus posiciones de poder temporal o espiritual, léase el rey o las jurisdicciones episcopal y papal. En un primer vistazo, nuestro texto podría parecer una obra de carácter meramente oral, en forma de sermón ${ }^{16}$; no hay rastro en él,

dios ya citados en las notas 7 y 8 , a los que pueden añadirse Nicholas Round, «La rebelión toledana de 1449. Aspectos ideológicos», Archivum 16 (1966) págs. 385-446; Alonso de Cartagena, Defensorium unitatis christianae (Tratado a favor de los judios conversos), ed. Manuel Alonso (Madrid: CSIC, 1943); Eloy Benito Ruano, Toledo en el siglo XV. Vida política (Madrid: CSIC, 1961); Alonso de Oropesa, Luz para el conocimiento de los gentiles, trad. de Luis A. DíAz y Díaz (Madrid: Fundación Universitaria Española, 1979); Santiago GARCÍA-JALÓN DE LA LAMA, «Los fundamentos jurídicos de la 'Sentencia-Estatuto' de Pero Sarmiento», en I Congreso de Historia de Castilla-La Mancha (Toledo: Junta de Comunidades de Castilla-La Mancha, 1988) vol. 6.1, págs. 201-204; Ramón Gonzálvez RuIz, «Fundamentos doctrinales de la Sentencia-Estatuto de Toledo contra los conversos (1449)», en Inquisición y conversos. Conferencias pronunciadas en el III Curso de Cultura Hispano-Judia y Sefardi de la Universidad de Castilla-La Mancha, eds. Ana María López Álvarez et al. (Toledo: Asociación de Amigos del Museo Sefardí Caja de Castilla La-Mancha, 1994) págs. 279-296; Enrique Cantera Montenegro, «El obispo Lope de Barrientos y la sociedad judeoconversa: su intervención en el debate doctrinal en torno a la 'Sentencia-Estatuto' de Pero Sarmiento», Espacio, tiempo y forma. Serie III, Historia medieval 10 (1997) págs. 11-29; Alonso Díaz de Montalvo, La causa conversa, eds. Matilde Conde Salazar et al. (Madrid: Aben Ezra, 2008), y Stefania PAstore, Una herejía española. Conversos, alumbrados e Inquisición (1449-1559) (Madrid: Marcial Pons Historia, 2010).

${ }^{16} C f$. [§20] «...si está en mi mano amputaré de vosotros, a quienes ahora hablo» [cum quibus de presenti sermo est]. Para mayor comodidad, en adelante citaremos de acuerdo con la traducción que consta al final del artículo, indicando asimismo el parágrafo, y con el texto latino entre corchetes en caso de interés. Formalmente destacan en 
sin embargo, de la estructura canónica del sermo thematicus, y, si se analizan más detalladamente su estructura, sus figuras retóricas y su andamiaje argumentativo, es patente que presenta todas las características de una obra escrita para un público más amplio: hipotetizamos, por lo tanto, que se trata de un texto de carácter político-religioso que oscila entre ambas formas de la oralidad y de la escritura (bien podría hallarse, en cierto modo, cerca de una epístola consolatoria o admonitoria).

El texto presenta un considerable conjunto de figuras retóricas necesarias para llamar la atención del auditorio y de los lectores: numerosísimos son los vocativos dirigidos al público, en expresiones como fratres in Christo karissimi en el íncipit, remplazado más adelante por fratres mei karissimi (una vez), fratres mei (cuatro veces) o simplemente fratres (cuatro veces) como inciso; también se encuentran la palabra dilecti (una vez) y su superlativo dilectissimi (dos veces). Estos apelativos contribuyen a recortar la distancia entre quien habla y quien escucha, incluyendo al auditorio en la exposición. Con el mismo objetivo se emplea la segunda persona del plural en las formas verbales para dirigirse al colectivo converso: queréis saber, os ruego, convertid, consolaos... No obstante, en cierto momento se asiste a un cambio:

[§33] Pero puesto que lo que recibimos de vosotros lo recibisteis primero de nosotros, deberíais estar agradecidos a nuestro linaje. Es evidente que la ley evangélica y apostólica que nos enseñasteis y que tenemos en común, el bautismo y los demás sacramentos eclesiásticos os los legaron los apóstoles y evangelistas de nuestro linaje, por inspiración divina.

Efectivamente, en este punto el autor deja de utilizar la segunda persona del plural para dirigirse a los cristianos nuevos, y la emplea para referirse a los cristianos viejos, que han aprendido su ley a partir del Viejo Testamento de los judíos; y sustituye la segunda persona del plural por la primera, incluyéndose a sí mismo, nítidamente, en la categoría de converso. Salvo esta excepción, se observa que quien escribe utiliza verbos en segunda persona del plural para incitar a sus fratres a resistir a quienes perpetran las persecuciones, asumiendo el papel de orador de una especie de sermón exhortativo:

el texto las interrogaciones retóricas y las pretericiones, figuras de las que podrían registrarse abundantes ejemplos, y que lo aproximan al sermón o discurso hablado. 
[§3] Os ruego, por tanto, hermanos, que no desfallezcáis en la tribulación, sino que vistáis la armadura de la fe y resistáis a tan grande adversario, fuertes en la fe. El enemigo es débil, no puede vencer más que a quien así lo desea; es muy astuto, pero solo en tanto que así lo tornáis.

A nivel retórico, el fragmento citado resulta interesante porque llama débil al enemigo, para luego calificarlo, por el contrario, de muy astuto: aun jugando con la evidente alusión al demonio, el adjetivo débil se debe necesariamente entender, no en sentido absoluto, sino en relación a la fuerza y a la inteligencia de los buenos cristianos; este tipo de acercamiento permite celebrar aún más las virtudes de los conversos y de sus defensores, a los cuales corresponde la tarea de debilitar y finalmente de vencer a sus adversarios, aunque sean muy astutos. La rebeldía toledana reviste, en consecuencia, un carácter diabólico, algo que también puso de manifiesto Díaz de Montalvo, por ejemplo ${ }^{17}$.

Cabe recordar que el gran valor de los que el autor considera como verdaderos cristianos es además otorgado, reconocido y valorado por el mismo Dios, como se ve en el pasaje siguiente:

[§74] Consolaos, pues, consolaos, pueblo de Dios, porque, al contrario de lo que estos hombres vanos e ignorantes dicen, la Sagrada Escritura, la fe católica y la Santa Iglesia de Dios no os reputa por viles y humillados, sino que os cree y predica como ilustres y gloriosos.

En efecto, aparece aquí el vocativo pueblo de Dios, que evidencia que los conversos están en la gloria de Dios, y no son humillados, sino gloriosos. Este pasaje se presenta elaborado retóricamente, también, por la repetición inicial Consolamini ergo, consolamini, que recuerda, por el procedimiento anafórico con el que se trata el tema de la consolación y exaltación de la espera de la gloria eterna, el pasaje bíblico de las bienaventuranzas del Evangelio según Mateo (Mt. 5.3-12): «Beati pauperes spiritu...; beati, qui lugent...; beati mites...», etc. Y efectivamente, el versículo 10 de este mismo pasaje evangélico es citado directamente en

17 Díaz de Montalvo, La causa conversa \$3, pág. 149: «De este modo también cuando algunos en nuestro tiempo, llenos de la influencia del espíritu maligno, cometen un pecado tan grande que para desmembrar la fe cristiana y hacer infieles a los fieles cristianos...». 
el texto que analizamos: [§12] «Bienaventurados -dice el Salvador- los que padecen persecución por justicia».

Volviendo una vez más los ojos a la forma retórica con la que está redactado nuestro texto, parece sobresaliente el hecho de que el autor apenas utiliza palabras que indiquen abiertamente la condición de conversos o cristianos nuevos, sino que sobre todo emplea el término christiani, aplicando verdadera y directamente en su escrito el principio de igualdad que propugna, sin operar divisiones ni siquiera de carácter lingüístico en el interior de la Iglesia católica, que en este sentido es etimológicamente católica, es decir, universal. Efectivamente, el autor hace una distinción exclusivamente entre christiani y heretici.

Por lo que se refiere a sus contenidos y su adscripción genérica, nuestro escrito podría caracterizarse, en efecto, como una consolatio: su finalidad es fortalecer la conciencia de grupo de los conversos y exhortar a estos a sobrellevar con paciencia y humildad los ataques que sufren por parte de algunos cristianos viejos. Hay, evidentemente, un acopio de conceptos y pensamientos de carácter doctrinal, pero todo lo que en otros escritos proconversos es su propia razón de ser, el fundamento teológico o canónico que los sustenta -se trata en el fondo de 'informes' técnicojurídicos-, se tiñe en nuestro texto de emoción y patetismo. La batería de demostraciones se supedita al designio primordial de confortar a los cristianos nuevos en tanto que verdaderos cristianos, de hacerles sacar fuerzas de flaqueza para resistir, en la convicción de que su posición es la correcta, la verdaderamente cristiana, y no la de quienes pretenden establecer diferencias entre hermanos. En los tramos finales del escrito se resume con claridad la intencionalidad de la Consolatio:

[§79] Veis, por tanto, queridísimos, cómo toda la Santa Escritura, con el ejemplo de Cristo y de los santos os invita tan eficazmente a la paciencia y tan dulcemente os consuela en las tribulaciones.

[§81] Os escribo estas cosas, hermanos, no en un estilo sublime ni con las palabras seductoras de la sabiduría humana, sino con compasión de ánimo, usando del lenguaje simple de la Sagrada Escritura, para que tengáis esperanza por medio de la paciencia y el consuelo de las Escrituras. Dios os dé paciencia y solaz, un mismo sentir, y aplaste velozmente a Satanás [bajo] vuestros [pies]. Que la gracia de nuestro Señor Jesucristo sea con vosotros. Amén. 
Un argumento que ya hemos mencionado arriba es la referencia al pueblo de Israel como pueblo elegido por Dios. Según el autor, los descendientes del linaje judío tienen que defenderse del enemigo, pero también tienen que estar orgullosos de su origen y aceptar que, con las persecuciones, Dios los está poniendo a prueba. Invirtiendo la situación, y siguiendo el precepto bíblico del ya mencionado discurso evangélico de las bienaventuranzas, los cristianos nuevos han de extraer Gracia de la desgracia; y en el sufrimiento que tienen que soportar son comparados con el mismo Cristo, que padeció el martirio en la cruz:

[§12] «Bienaventurados - dice el Salvador- los que padecen persecución por justicia», y en esto os igualáis más verdaderamente al propio Salvador Cristo nuestro Señor, guardando aquello que vuestro apóstol Pedro exhorta en su cánonica: «Y pues Cristo padeció en la carne -dice-, armaos también del mismo pensamiento»; seguros de que, si sufrís con Él, también reinaréis con Él y, si lo acompañáis en sus pasiones, tendréis parte también de sus consolaciones.

Nos parece esencial, igualmente, la alusión a la crucifixión de Jesús, ya que uno de los argumentos antisemitas más recurrentes fue la culpabilidad del pueblo judío en el asesinato de Cristo. La polémica acerca de la figura de Cristo es un tema central de la cuestión judía y conversa, dado que, por un lado, los anticonversos acusaban al pueblo judío de haber matado al Mesías, mientras que, por otro lado, los proconversos se gloriaban del hecho de pertenecer al mismo linaje de Jesús. Sobre la muerte de Cristo, el texto analizado insiste en evidenciar la responsabilidad conjunta del pueblo gentil, que también asesinó al Mesías con la indiferencia de Poncio Pilato y las humillaciones por boca de los soldados gentiles:

[§54] Pero si por unos pocos quieren hacer a todo el linaje judío reo de su muerte, condénese también a toda la estirpe gentil porque Pilatos, gentil, lo sentenció, y sus soldados, gentiles, lo crucificaron, y se burlaron de él ofreciéndole vinagre y diciéndole: «Si eres el rey de los judíos, sálvate a ti mismo».

Al igual que ambos linajes, explica el autor, los descendientes de los gentiles y los descendientes de los judíos son culpables en la misma medida de la muerte de Cristo, y ambos de igual manera pueden acceder a la Gracia divina, que acoge sin distinción a quienes se redimen: 
[§57] Concluyamos, pues, con el apóstol, que todos pecaron, gentiles y judíos, y que todos tienen necesidad de la gloria de Dios, y que ya no hay diferencias entre judío y griego, y que Dios no hace acepción de personas, sino que cualquiera que invoque el nombre de Dios se salvará.

La negación del poder salvífico de la redención sería, consiguientemente, una herejía. Además de negar el poder ilimitado de la Gracia, los calificados como herejes también niegan la función salvífica del bautismo, tema que asimismo se refleja en la Instrucción del Relator y que es central en otra obra proconversa, la de Alonso Díaz de Montalvo, que fue incluida en un segundo momento en su recopilación del Fuero Real de España ${ }^{18}$. El sacramento del bautismo limpia los pecados de todos los cristianos, sin atender a sus pecados anteriores: tras él, por lo tanto, no subsisten motivos para hacer una distinción de sangre entre cristianos.

La cuestión de la sangre, por otro lado, es presentada por el autor del escrito que analizamos aquí como un privilegio en favor de los cristianos nuevos: además de las referencias a Cristo, se insiste sobre la semejanza con los apóstoles, que también eran de linaje judío, y sobre los orígenes de la primera iglesia, cuyos representantes, a partir del primer pontífice San Pedro, eran también de esa misma estirpe. De esta forma, nuestro anónimo autor quiere presentar el hecho de descender del pueblo de Israel no como algo despreciable, según afirmaban los defensores de la Sentencia-Estatuto de Pedro Sarmiento, sino más bien como un valor añadido, un rasgo de semejanza que acerca a los cristianos nuevos a Cristo y a la doctrina cristiana, aún más que a los cristianos viejos. En este sentido, los cristianos nuevos son también comparados con los

${ }^{18}$ Cf. Díaz de Toledo, Instrucción del Relator, págs. 98-99 (citamos por González Rolán y Saquero Suárez-Somonte, De la 'Sentencia-Estatuto' de Pero Sarmiento): «y tan gran error sería esto en la fee, como si dixese que por venir en conoçimiento de ella, avían tal malefiçio, y que quedasen infames y no pudiesen aver ofiçios, nin benefiçios, ni honras ni dignidades, ya que el sancto baptismo, y la eficaçia de él, el qual façe el baptiçado nuevo hombre y lo lava y lo quita de todo reato y culpa y pecado y sequela de pecado, quedaría evacuado y como si no uviera fecho ni obrado en el hombre el baptismo todo su efecto quedando en él qualquier mançilla o defecto: lo qual sería notoria heregía»; Díaz DE MonTALvo, La causa conversa §17, pág. 160: «En efecto, ahora las cualidades y efectos del agua del bautismo tienen el mismo efecto que tenían en tiempos de San Pedro, el príncipe de los apóstoles; afirmar otra cosa es manifiesta herejía». 
mártires, que padecieron injustamente por llevar con orgullo una condición que era tenida por sus atacantes como despreciable, cuando en realidad se trataba de un timbre de gloria. Los anticonversos son, por el contrario, equiparados a los antiguos emperadores paganos. Con ello va esclareciéndose más aún la idea de que no existen dos tipos de cristianos, sino solamente las dos categorías de cristianos y no cristianos (esto es, de auténticos cristianos frente a herejes perseguidores de cristianos):

[§23] Si el más cristiano os contradice: «Es mejor sentir alegría que tristeza, siguiendo el ejemplo de aquellos apóstoles que salieron de la presencia del sanedrín contentos, porque se habían hecho dignos de padecer ultrajes por el nombre de Jesús», aunque no ha de presumirse que un cristiano vitupere en nosotros lo que cree merecedor de la mayor alabanza en sí mismo; si, en fin, y ojalá no sea así, alguien hace esto en su ignorancia, os está llamando discípulos de Cristo, pero él se erige en imitador de Nerón, de Domiciano, de Diocleciano, de Maximiano, de Juliano el Apóstata y de sus esbirros, que hicieron causa para ejercer su crueldad con los santos de Dios, igual que hoy hacen los mahometanos. [§24] Si se nos reprochan a nosotros, señaladamente más que a los demás, la avaricia, la soberbia, la envidia y los demás pecados que son comunes a prácticamente todos los hombres, examinaos a vosotros mismos, amadísimos, y si encontráis en vosotros tales pecados, el remedio será abstenerse de ellos y expulsar de vuestras mentes los deseos carnales que militan contra el alma, y hacer siembra con los granos de las virtudes para que den un fruto céntuplo.

En este pasaje se encuentran referencias a los pecados generalmente imputados a los judíos: avaricia y soberbia, la primera por ser una acusación antisemita recurrente, la segunda quizás también por los puestos prestigiosos que a menudo los conversos desempeñaban en la administración pública. La recomendación del autor a los cristianos nuevos es la de controlar sus propias conciencias para autorregularse.

En esta misma línea de autoanálisis surge otro argumento de la parte proconversa: a favor de los cristianos de descendencia judía sinceramente convertidos jugaba el principio de que, si bien es evidente que los judíos pecaban por el mero hecho de no reconocer a Cristo, no por ello todo el linaje había de ser condenado en tanto que linaje, cuando obraba la conversión:

[§62] Y puesto que los judíos que hoy se mantienen en su ceguera, aunque no todos son hijos en cuanto a la carne de aquellos que crucificaron 
a Jesús, son todos sus hijos en cuanto a la imitación del pecado, pues no creen que Jesús sea Cristo y el verdadero Dios, sino un simple hombre mentiroso y blasfemo; realmente, estos lo crucifican todos los días. Es digno y justo que, mientras dure la culpa de su falta de fe, deba durar su pena de miseria y cautiverio. [§63] Pero no es así, por cierto, para vosotros, hermanos míos, que, aunque fueseis hijos de aquellos en cuanto a la carne, no sois imitadores de los crímenes paternos. Antes bien, abandonada la tiniebla de la falta de fe, es necesario que creáis de corazón, para ser justos, y que con la lengua reconozcáis, para salvaros, que la verdadera luz que ilumina a todo hombre que llega a este mundo, esto es, nuestro Señor Jesucristo, Dios y Hombre verdadero, resucitó de entre los muertos por nuestros pecados, por nuestra justificación, con otros dogmas necesarios para la salvación.

Este es un discurso que también se encuentra en Díaz de Toledo y en Cartagena; tanto es así que Nicholas Round ha interpretado el Defensorium casi como una incitación a la creación de una Inquisición para castigar a los infieles y distinguirlos de los buenos cristianos, cuyo nombre resultaría así limpiado:

lo que Alonso de Cartagena había reclamado era la Inquisición. Esta, pues, debió su existencia al intento de discriminar, mediante una máquina jurídica creada especialmente para tal propósito, entre acusaciones verdaderas y falsas. Tal discriminación fue considerada una necesidad porque se les acusaba a todos los conversos de ser herejes ${ }^{19}$.

En la dirección de demostrar que, por más que en todas las razas o naciones hay individuos malos, ello no significa que las naciones sean malas de por sí y sin remisión, nuestro texto hace una comparación también con los judíos que crucificaron a Cristo, y en esta ocasión ofrece una reflexión filológica acerca del indefinido omni para disculparlos, una vez más, de la acusación infamante de deicidio:

[§50] Con mansedumbre podéis responder que, aunque algunos pocos de vuestra raza, los príncipes de los sacerdotes y los fariseos de aquel tiempo, que sentían por Él envidia y odio porque a ellos los reprendía

${ }^{19}$ Nicholas Round, «La rebelión toledana de 1449», pág. 444. Sobre el Defensorium es muy útil también Luis Fernández Gallardo, «Teología y derecho en el Defensorium de Alonso de Cartagena», en Comunicación y conflicto en la cultura política peninsular (siglos XIII al XV), coords. José Manuel Nieto Soria y Óscar Villarroel (Madrid: Sílex, 2018) págs. 559-588. 
más que a los demás, mediante sus ministros entregaron a Cristo y lo acusaron y con sus lenguas lo crucificaron, ello no lo hicieron todos los judíos de su tiempo, porque los oriundos de otras tierras, cuyo número era casi infinito, dispersos por todo el mundo a causa de las persecuciones precedentes, no estuvieron presentes allí; por tanto, ni todos pudieron haber acudido al día festivo, por más que fuese un precepto legal, porque la cautividad y otras causas y asuntos excusaban legítimamente su ausencia. [§51] Y no es un impedimento que se lea que vinieron a la festividad «de todas las naciones» [de omni nacione], porque la palabra 'todas' no tiene aquí un sentido distributivo que equivalga a todos y cada uno de los pertenecientes a una nación, sino que más bien se toma por las naciones de esos individuos, de manera que 'de todas las naciones' significaba aquí 'algunos', vale decir 'algunos hombres piadosos', pero no todos y cada uno de aquellas naciones.

El argumentario anticonverso echó mano repetidamente de varios cánones del Decreto, de los que quería deducirse que era la propia Iglesia la que prohibía, de un lado, ordenar a los neófitos como obispos; y de otro lado, admitir a oficios públicos a los judíos o sus descendientes (canon Constituit: Qui Iudei aut hii qui ex Iudeis sunt) ${ }^{20}$. Prácticamente todos los tratados proconversos se afanan en desmontar la fuerza probatoria de estos cánones, como igualmente hace nuestro texto. Se arguye, así, que los neófitos aludidos en el Decreto no son per se los conversos del judaísmo, sino todos los convertidos recientemente, del judaísmo o la gentilidad, que deben superar una etapa de noviciado y perseverar en la fe antes de poder recibir órdenes sagradas; una vez superada esa etapa, los convertidos han de ser considerados como auténticos cristianos:

[§64] Aquello de que los neófitos no pueden ser ordenados es pueril. Os lo lanzan como una injuria quienes desconocen la interpretación y significación de la palabra o no quieren atender diligentemente los decretos que hablan de esta materia. Neófito se traduce como 'nuevo' o 'inexperto en la fe', o 'convertido recientemente a la fe', y el apóstol prohíbe que este sea ordenado como tal, porque todavía no está instruido

${ }^{20}$ Véase por ejemplo la Apelación y suplicación del bachiller Marcos de Mora, y la propia bula de 24 de septiembre de 1449 de Nicolás V (en GonzÁlez Rolán y SAQuero SuÁrez-Somonte, De la 'Sentencia-Estatuto' de Pero Sarmiento, págs. 219-220 y 248). Para las referencias del Decreto, $c f$. las notas 91-92 de la edición. 
en las cosas que tocan a la fe ni ha sido probado sobre aquellas cosas que convienen a la religión cristiana.

En el mismo sentido, se refuta la interpretación del canon Constituit como una inhabilitación manifiesta de todos los descendientes de judíos para el desempeño de cargos públicos, cuando es claro que debe referirse tan solo a aquellos que no han ingresado en el cristianismo de manera sincera y han abandonado su religión o la de sus padres ${ }^{21}$. Es más, los judíos en los que se ha operado la verdadera conversión poseen una suerte de prerrogativa que sigue distinguiéndolos como pueblo elegido, en la medida en que han aceptado que las antiguas promesas de Dios se cumplen de manera perfecta en Cristo:

[§71] San Ambrosio afirma lo opuesto, cuando trata de aquellas palabras del apóstol a los Romanos, Al judío primero, también luego al griego: «Nombra primero - dice- al judío, por prerrogativa de los Padres, o bien para ser ensalzado antes, o bien para ser condenado con más severidad», algo que antes de San Ambrosio sancionaba claramente San Clemente, quien, predicando a los judíos la fe de Cristo, como narra la historia eclesiástica, usaba de este orden, concediéndoles esta gracia, y afirmaba que sus ascendientes habían sido amigos de Dios y conmemoraba que su ley era santa y sacratísima. [\$72] Y añadía que ellos obtendrían el primer lugar si guardaban los sacramentos de su ley, no negando que la promesa de Dios a Abrahán había sido completada en Cristo, esto es, que Dios prometió que todas las gentes tendrían parte de la herencia de la semilla de Abrahán.

A este mismo efecto se recuerda un pasaje revelador de San Pablo (Rom. 11-15-24):

[§76] ...y añade: «Porque si su reprobación es reconciliación del mundo, ¿qué será su reintegración sino una resurrección de entre los muertos? Pues si las primicias son santas, también la masa; si la raíz es santa, también las ramas. Y si algunas de las ramas fueron desgajadas, tú, siendo acebuche, fuiste injertado en ella y hecho partícipe de la raíz y de la enjundia de la oliva. No te ensoberbezcas contra las ramas, pues

${ }^{21}$ La Respuesta a una duda sobre si los judios pueden desempeñar cargos públicos de Lope de Barrientos se dedica enteramente a interpretar este canon desde una perspectiva proconversa (González Rolán y Saquero SuÁrez-Somonte, De la 'Sentencia-Estatuto' de Pero Sarmiento, págs. 143-191). 
si te vanaglorias, no sustentas tú a la raíz, sino la raíz a ti. Dices: las ramas fueron desgajadas para que yo fuera injertado. Bien: por su incredulidad fueron desgajadas, y tú por la fe estás en pie. No te engrías, antes teme; porque, si Dios no perdonó a las ramas naturales, tampoco a ti te perdonará. Considera, pues, la bondad y la severidad de Dios; la severidad para los caídos, para contigo la bondad, si permaneces en la bondad, que de otro modo también tú serás desgajado. Mas ellos, de no perseverar en la incredulidad, serán injertados, que Dios es poderoso como para injertarlos de nuevo; porque, si tú fuiste cortado de un olivo silvestre y contra naturaleza injertado en un olivo legítimo, ¡cuanto más estos, los naturales, podrán ser injertados en el propio olivo!».

El pasaje susodicho, que presenta la metáfora de una planta cuyas raíces, como las de la Iglesia católica, son judías y en cuyas ramas ha sido injertada la cristiandad, ofrece una imagen potente para la causa proconversa, como evidenciaba ya Albert Sicroff hablando del Defensorium de Cartagena, que empleaba igualmente el mismo paso de San Pablo:

Alonso de Cartagena se sirve de la imagen del olivo de San Pablo para mostrar que Israel es el árbol sagrado del que fueron podadas ciertas ramas estropeadas a fin de injertar en su lugar ramas gentiles. Pero que los gentiles no se glorifiquen y que sepan que es la raíz la que los sostiene y no ellos quienes sostienen la raíz ${ }^{22}$.

Nuestro texto se cierra con un apéndice en que se recogen siete conclusiones vel sentencie que compendian de manera categórica el alcance herético, escandaloso, temerario y cismático de las opiniones anticonversas. El recurso es muy similar al del sermón de 1449 pronunciado en Valladolid ante el rey, que hemos sugerido que tal vez pudiera deberse a la misma pluma que la Consolatio (ítem [5] del ms. 14), aunque ha de subrayarse que este tipo de acusaciones, y el propio procedimiento de extraer propositiones suspectas y calificarlas de acuerdo con las 'notas teológicas' censorias, son comunes en la literatura de ambos bandos ${ }^{23}$. A las siete conclu-

22 Albert A. Sicroff, Los estatutos de limpieza de sangre. Controversias entre los siglos XV y XVII (Madrid: Taurus, 1985) pág. 67. Cf. Cartagena, Defensorium II.1.4.

${ }^{23} C f$. sobre los procedimientos María José Vega Ramos, «Notas teológicas y censura de libros en los siglos XVI y XVII», en Las razones del censor: Control ideológico y censura de libros en la primera Edad Moderna, coord. Cesc Esteve (Bellaterra: Universidad Autónoma de Barcelona, 2013) págs. 25-53. 
siones les sigue una exhortación final a las autoridades espirituales y temporales para que tomen cartas en el asunto y castiguen como herejes a los rebeldes, lo que nos parece que sitúa nuestro texto en una fecha anterior a la divulgación en Castilla de las bulas proconversas de Nicolás V (esto es, en los meses anteriores a octubre-noviembre de 1449) ${ }^{24}$ :

[§82] Los príncipes eclesiásticos y temporales han de proceder, de acuerdo con ambos derechos y con las normas, contra los citados herejes, hombres inicuos y blasfemos, y castigarlos con la condena que corresponda, porque pecarán mortalmente si no lo hacen.

Es importante destacar, a este propósito, que la rebelión toledana de 1449 se originó primeramente, según la interpretación de Eloy Benito Ruano, como rebelión antimonárquica de una parte de la ciudad de Toledo en contra del rey Juan II, y solo en un segundo momento se justificó a través de motivaciones jurídico-religiosas con la Sentencia-Estatuto de 5 de junio de 1449 que, recordémoslo, fue el primer estatuto de limpieza de sangre de la historia de España ${ }^{25}$. Así, el texto analizado termina precisamente con la invitación a los soberanos y autoridades eclesiásticas a castigar a los herejes, advirtiéndoles de que, de no hacerlo, ellos mismos se mancharían del pecado de herejía.

\section{Conclusiones}

Hemos comprobado cómo el texto que aquí editamos se inscribe en la tradición de obras proconversas redactadas con ocasión de la rebelión

${ }^{24} C f$. Vicente Beltrán de Heredia, «Las bulas de Nicolás V acerca de los conversos de Castilla», Sefarad 21 (1961) págs. 22-47, y González Rolán y Saquero SuÁrezSomonte, De la 'Sentencia-Estatuto' de Pero Sarmiento, págs. 243-299.

25 Véase Bentto Ruano, Toledo en el siglo XV, pág. 47: «Pero Sarmiento precisaba poseer algún argumento aducible, ya por su legalidad o por su popularidad, para explicar su conducta ante los de fuera y justificarse convencionalmente entre los de dentro. El común de Toledo necesitaba también de una justificación más sólida que la del desatamiento de sus pasiones para convencerse a sí mismo de la licitud del alboroto y esgrimir esta en defensa de su actitud. A uno y a otros vino a dar pretexto, como tantas otras veces, el latente problema judío. Activa o pasivamente, los judíos primero, los conversos después, están de modo efectivo o pretextado, en la historia visible o encubierta de la mayoría de los disturbios toledanos, a lo largo de la Edad Media y parte de la Moderna». 
toledana de 1449, y cómo, si bien por un lado aborda los temas típicos del debate proconverso, por otro lado ofrece una perspectiva inédita, un punto de vista mixto entre la visión de los llamados cristianos viejos proconversos y la visión de los cristianos nuevos perseguidos ${ }^{26}$, privilegiando sin embargo la perspectiva de estos últimos, ilustrado todo ello con la ayuda de herramientas retóricas eficaces. En este sentido, y a pesar de su brevedad y de haber sido ignorada hasta el momento, la Consolatio que editamos nos parece significativa en su originalidad y particularidad única de enfoque, y por esta razón esperamos que en un futuro próximo sea tenida en cuenta en los estudios historiográficos sobre la materia conversa.

\section{EDICIÓN Y TRADUCCIÓN DEL TEXTO 27}

[§1] [fol. 128ra] Queritis, fratres in Christo karissimi, quid sibi vult istud novum genus belli. Ego vero non dico novum, sed antiquum; renovantur si quidem persecutiones antique. Occulto nanque Dei iudicio, non tamen iniusto, temptare nititur hostis antiquus illos duos parietes quos lapis ille angularis Christus Dominus noster sibi univerat; [\$2] sibi invicem disiungere, ad se invicem repugnare, videns ita nos qui [quos?] ex circumcisione credidistis, quos prius quasi vernaculos possidebat, a iugo servitutis sue liberos, fidemque Christi, per quam via est ad celum unde ipse

${ }^{26}$ A este propósito cabe decir que, si bien los autores del Defensorium o de la Instrucción del Relator no eran cristianos viejos, sino cristianos nuevos, el punto de vista que privilegian en sus tratados es el de los primeros, que según ellos tienen que respetar y defender a los nuevos como a hermanos en la fe.

27 Se ha respetado la ortografía del manuscrito (regularizándose tan solo la distribución de $u / v$ ). Una característica llamativa de toda la segunda parte del códice es el uso anómalo de $s$ y $c$ (cermo, paciensie, ansilla, sentensiavit, sisma...), tal vez síntoma de una confusión de sibilantes en el habla vernácula del copista. Se han desarrollado en silencio las abreviaturas y las enmiendas del propio copista, y se ha modernizado la puntuación (prácticamente inexistente en todo el códice, lo que ha generado no pocos problemas de comprensión). Las escasas intervenciones editoriales van invariablemente entre corchetes. Se emplean, además, la abreviatura $m s$. para señalar lecturas del manuscrito, y el signo $\uparrow$ para palabras o pasajes posiblemente corruptos, que no hemos sido capaces de resolver satisfactoriamente. Hemos segmentado, en fin, el texto en parágrafos numerados, para facilitar el cotejo con la traducción castellana. 
corruerat, per nos filiosque nostros iugiter propagari invidet, et tactus dolore inmanitate persecutionum conatur in nobis fidei fundamentum evertere quod archite[c]tus noster suo purissimo sanguine solidavit.

[§3] Obsecro ergo vos, fratres, ne defficiatis in tribulacione, sed armamini lorica fidei et tanto adversario resistite, fortes in fide ${ }^{28}$. Debilis enim hostis est, non vincit nisi volentem ${ }^{29}$; astutissimus est, sed $\dagger$ in tantum eum reddetis $\uparrow$. Sed persecucionem istam, que occasionem ruine vel scandali preparat, in materiam virtutis vel meriti, sufulti divino munere, converta- [fol. 128rb] tis. [\$4] Sepe enim accidit illi tyranno, quem Salvator noster principem huius mundi nominat ${ }^{30}$, quod si cum humili christiano forti tamen ad dimicandum veniat, credit dicere [vincere?] et promovet, sicque fraudatus desiderio suo recedit confusus, fvictorem quem victus $\dagger$ fugit et a persecucione quiescit.

[§5] Unum est quod valde timeo, ne mundanis prosperitatibus assueti, adversitatum insoliti, malis presentibus prosternamini. Absit hoc a vobis, dilectissimi, qui in sacra Veteris Testamenti ystoria legistis quanta patres vestri a Pharaone in Egipto, quanta in deserto duce Moyse mala perpessi sunt. [§6] Quorum qui per inpacienciam Dominum irritaverunt ibidem cadentes ad terram desiderabilem non pervenerunt; constantes et cum fiducia flagellum Domini inscientes, fructu terre sublimi digni effecti requiem Domini ingressi sunt ${ }^{31}$. Melius me nostis quot hostiles incursus idem patres vestri postea temporibus Iudicum et Regum, ex[c]epto illo paciffico Salomonis tempore usque ad captivitatem Babilonis inclusive, a Philisteis et aliis barbaris nationibus fere sine intermissione sustinuerunt. [§7] Quid preterea redeuntes de captivitate a convicinis gentibus in rehedifficacione Templi, regnantibus Perssis; quid postea a Grecis sub [fol. 128va] Antioco; quid a Romanis, revelata iam veritate, finaliter passi

281 Thess. 5,8: «simus induti loricam fidei et caritatis et galeam spem salutis». Las citas bíblicas de la Vulgata pretridentina se realizan de acuerdo con Biblia sacra Vulgata (quinta editio), eds. Robert Weber, Roger Gryson et al. (Stuttgart: Deutsche Bibelgesellschaft, 2007).

${ }^{29}$ La cita corría en diversas formulaciones, y atribuida a diversos autores. Por ejemplo Pelag. epist. ad Demetr. 25 (PL 30, col. 40): «Infirmus hostis est qui non potest vincere nisi volentem». $C f$. también Aug. $c i v .20 .8$.

30 Io. 12,31 .

${ }^{31}$ Is. 4,2: «et fructus terrae sublimis et exultatio his qui salvati fuerint de Israhel». 
fuerunt longum esset scribere. [ $\$ 8]$ Persecuciones, igitur, non sunt aliene a nacione nostra, apropriate sunt generi nostro. Que si veniant non est de eis mirandum quasi novum aliquid accidat ${ }^{32}$, sed ut minus feriant assuetos, provisos, preparatos vult Deus quod nos reperiant. [§9] Qui iuxta dictum Sapientis: "Quem diligit corripit et quasi pater in filio conplacet sibi» ${ }^{33}$; in Filio, inquam, suo unigenito, sibi coequali, sibi coeterno et consubstanciali [consubstancialem $m s$.], quem a regalibus sedibus mittens ut filio[s] Abrahe dispersos in unum colligeret ${ }^{34}$, carnem de illo semine sibi univit. [§10] Tunc enim quomodo Verbum caro factum et habitavit in nobis ${ }^{35}$, non illum diviciis nec deliciis vel honoribus huius seculi implicari voluit, sed ut ipse nobis preberet exemplum humilitati[s], paupertati[s], paciensie, dum in terris cum hominibus conversaretur, ad ultimum acerbe passioni et ignominiose morti pro nobis omnibus tradidit illum.

[§11] Itaque, fratres mei karissimi, si rapinam bonorum patimini ${ }^{36}$, quid aliud est nisi quod vult Pater vester celestis vos ab avaricie ignibus et superflua solicitudine diviciarum elongare et in tranquilla paupertate cum Filio suo costituere? Si ex alia, si famem, sitim, nudita[tem], mortes, cruces, credo sic esse, ut audio, quod propter iusticiam regis nostri [fol. 128vb] a sibi inobedientibus et rebellibus sustinetis, beati estis ${ }^{37}$. [§12] «Beati -inquit Salvator- qui persecucionem patiuntur propter iusticiam ${ }^{38}$, et in hoc eidem Salvatori Christo Domino nostro verius conformamini, tenentes id quod appostolus vester Petrus in sua canonica exortatur: «Christo -inquit- passo in carnem et vos eadem cogitacione armamini» ${ }^{39}$; securi quod si compatimini, et conrregnabitis et, si socii fueritis passionum, eritis et consolationum ${ }^{40}$. Vult ergo Deus, sub sua omnipotenti manu, vos in hoc

321 Petr. 4,12: «carissimi nolite peregrinari in fervore qui ad temptationem vobis fit quasi novi aliquid vobis contingat».

33 Prov. 3,12.

${ }^{34}$ Io. 11,52: «ut filios Dei qui erant dispersi congregaret in unum».

35 Io. 1,14 .

${ }^{36}$ Hebr. 10,34: «et rapinam bonorum vestrorum cum gaudio suscepistis».

371 Petr. 3,14: «sed et si quid patimini propter iustitiam beati».

38 Mt. 5,10.

391 Petr. $4,1$.

402 Cor. 1,7: «quoniam sicut socii passionum estis sic eritis et consolationis». 
perituro seculo cum Filio suo humiliare, ut in terra vivencium cum Eodem eternaliter exalt[emini] [exaltat $m s.]^{41}$. [\$13] Multum ergo vos diligit quos facit cum unico Filio suo similes in vita, pares suo modo in disciplina, conformes in premio. Respicite, dilecti, ubi nunc sint appostoli, fratrueles vestri, quibus ipse Dei Filius disposuit Patris sui regnum quia perfecti imitatores eius vivendo et paciendo extiterunt, ut edant et bibant super mensam suam in regno suo; sessuri in illo finali et tremendo iudicio super duodecim sedes, iudicantes duodecim tribus Israel ${ }^{42}$. [§14] Martiribus et aliis sanctis totus orbis pariter congratulatur, qui et si coram hominibus tormenta passi sunt, spes eorum inmortalis est in eternum. Non ergo habetis iustam causam querele ad Deum quia vos [fol. 129ra] flagellat, sed magis graciarum accionem quia vos tamquam filios emendat et velut aurum in fornace ut electos suos probat ${ }^{43}$.

[§15] De vestris quidam acerrime respondent: «Libet sufferre persecucionem repentinam quam adversarius noster hac tempestate suscitavit; credimus enim per Dei misericordiam, cooperante regali ministerio, non diu duraturam, sed brevissime terminandam. Sed quis opprobria iugiter exprobancium pacienter poterit tollerare? [§16] Insultant nobis Iudei ex una parte, dicentes nos a via recta deviasse et a lege veritatis apostatasse, et ideo devios, apostatas, non conversos sed aversos perversosque nos reputant et, quoniam inpune possunt, sic nos publice nominant. [\$17] Ex alia parte christiani, qui nos confortari et consolari deberent, ad quorum predicacionem fidem ortodoxam suscepimus, per quam eis nos unimus et spiritualiter incorporavimus, firmiter cum eis credentes et simpliciter confidentes unum Deum trinum et unum, eandem fidem, sacramenta eadem, ritus non diversos, sed illos eosdem quos ab eis didicimus et Sancta Romana Ecclesia Catholica et Appostolica tenet et approbat sequimur et tenemus cotidie, contra nos murmurant, nobis detrahunt contumeliosa verba et maledicta cantando et colloquando, in singulos [fol. 129rb] et universos subsanantes et irridentes, quod pro solacio sine causa profferunt. Angustie sunt nobis undique. Videat Deus et iudicet, nec nos sua pietas derelinquat».

41 Cf. 2 Cor. 11,7: «me ipsum humilians ut vos exaltemini».

42 Mt. 19,28: «cum sederit Filius hominis in sede maiestatis suae sedebitis et vos super sedes duodecim iudicantes duodecim tribus Israhel».

43 Cf. Prov. 27,21 y Sap. 3,6. 
[§18] Video, proh dolor, fratres, quod porta magni scandali aperitur, verumptamen ve homini illi per quem scandalum venit! ${ }^{44}$; et scandalizantibus timeo ne eveniat malum quod Redemptor noster in Evangelio cominatur: "Qui scandalizaverit -inquit- unum de pusillis istis minimis qui in me credunt expedit ei ut suspendatur mola asinaria in collo eius et demergatur in profundum maris», et maledictio appostoli dicentis: «Utinam abscindantur qui vos conturbant» ${ }^{45}$. [\$19] Vos vero qui edocti estis pro persecutoribus exorare et vincere in bono malum ${ }^{46}$, quid aliud opportet facere nisi cum eodem Magistro nostro flagellato et cruci affixo clamare ad Patrem et dicere: «Pater, dimitte illis quia nesciunt quid faciunt»? ${ }^{47}$ [\$20] Sed quia nec sic estis dispositi quod ista perfectionis doctrina vobis sufficiat, aliter a vobis, cum quibus de presenti sermo est, materiam passivi scandali, si potero, amputabo, vel si tamtum non valebo saltem extenuare conabo, ne vos demergat tempestas tribulacionis nec absorbeat [nec urgeat] super vos puteus tristicie os suum ${ }^{48}$. [\$21] Ad quod faciendum sufficiebat [fol. 129va] illud quod appostolus vester Iacobus Ierosolimitanus duodecim tribubus dispersionis eo tempore similia passis scribens ait: «Omne gaudium existimate, fratres mei, cum in temptationes varias incideritis scientes quod probacio fidei vestre passienciam operatur. Paciencia autem opus perfectum habet, ut sitis perfecti et integri, in nullo defficientes» ${ }^{49}$.

[§22] Nichilominus, quia teste Philosopho in Moralibus, sermones universaliores sunt inaniores et non tante efficacie ${ }^{50}$, opportet ad infe-

${ }^{44}$ Mt. 18,7: «vae mundo ab scandalis necesse est enim ut veniant scandala verumtamen vae homini per quem scandalum venit».

45 Gal. 5,12.

46 Mt. 5,44: «orate pro persequentibus et calumniantibus vos»; Rom. 12,21: «noli vinci a malo sed vince in bono malum».

47 Lc. 23,34

48 Ps. 68,16: «non me demergat tempestas aquae neque absorbeat me profundum neque urgeat super me puteus os suum». La manipulación de la cita ha hecho que el autor haya trastocado los verbos y haya usado absorbeat en lugar de urgeat.

49 Iac. 1,2-4.

${ }^{50}$ Arist. Eth. 2.7.7; 1107a28-33 (Aristoteles Latinus, XXVI, 1-3/3. Ethica Nicomachea. Translatio Roberti Grosseteste Lincolniensis sive 'Liber Ethicorum'. A. Recensio pura, ed. Renatus Antonius GauthIER (Bruges-Paris: Desclée de Brouwer-Leiden: Brill, 1972) pág. 172: «In hiis qui circa operaciones sermonibus, universales quidem inaniores 
riora descendere et cognoscere speciffice causam morbi ut remedium non ignoretur; expedit ergo scire que sunt ista opprobria de quibus tan acriter causamini. [\$23] Si christianisimus vobis opponitur: «Gaudendum est pocius quam tristandum, exemplo ipsorum appostolorum qui gaudentes ibant a conspectu consilii, quia digni habiti sunt pro nomine Ihesu contumeliam pati» ${ }^{51}$, licet non est presumendum quod christianus in nobis vituperet quod in se ipso maxime laudandum credit; demum si, quod absit, aliquis ignoranter hoc faciat, iam vos discipulos Christi dicit, ille vero Neronis, Domiciani, Diocleciani, Maximiani, Iuliani Apostate satelitumque eorum qui hanc causam seviendi in sanctos Dei sumebant, et hodie mahumetiste sumunt, se imitatorem constituit. [\$24] Si avaricia, superbia, invidia et cetera ${ }^{[\mathrm{fol} .129 \mathrm{vb}]}$ crimina que comunia fere sunt omnibus hominibus in nobis signanter plusquam in ceteris arguuntur, vos metipsos examinate, karissimi, et si talia in vobis reperiuntur, remedium est abstinere et carnalia desideria, que militant adversus animam, a conscienciis vestris eveller[e] [evellerunt $m s$.], et granis virtutum que faciant fructum centuplum eas seminare ${ }^{52}$. [\$25] Superbiam namque in humilitatem, avaritiam in liberalitatem, luxuriam in castitatem, invidiam in caritatem, si mutaveritis iam maledicentis vituperium in paternam increpacionem conversum est. Tristetur ille maledicus qui perdidit virtutem, letare tu quia eam recuperasti; lugeat ille quia manet Dei inimicus, tu gaude quia effectus es eius amicus. Bonum ergo fuit illud vituperium quod tantum bonum tibi coopertum est. [\$26] Si prefacta crimina de quibus vituperamini in vobis non inveniuntur, nichil vos ledit, maledicus in nullo vobis nocet contumeliosus. Dicat quilibet vestrum cum appostolo: "Gloria mea hec est, testimonium consciencie mee" ${ }^{53}$, nec curo quid dicant homines qui ista exteriora precise vident, quia arbitrari non est nostri quod quisque loquatur, vere de me iudicare solus Ille [fol. 130ra]

sunt, particulares autem veriores»; un texto más cercano al citado aquí aparece en el aparato de la edición, como glosa).

${ }^{51}$ Cf. Inocencio III, Reg. 10.159 (PL 215, col. 1252): «Si qua ergo vobis immineat adversitas propter ipsam, gaudendum est vobis potius quam tristandum, apostolorum exemplo, qui teste Scriptura: 'Gaudentes ibant a conspectu concilii, quoniam digni sunt habiti contumeliam pro nomine Iesu pati' (Act. 5,41)».

52 Lc. 8,8: «et aliud cecidit in terram bonam et ortum fecit fructum centuplum».

532 Cor. 1,12: «nam gloria nostra haec est testimonium conscientiae nostrae». 
novit qui renes scrutatur et corda» ${ }^{54}$. [\$27] Hoc voluit scola stoycorum domatizantium quod in sapientem non cadit iniuria ${ }^{55}$, quia nichil reputat malum nisi turpe vel vicium, nec bonum nisi honestum vel virtutem ${ }^{56}$; ad veritatem [?] sapiens vel virtuosus si ad tempus iniuria vel aliis infortuniis turbetur, numquam tamen perturbatur, quia a bono rationis nunquam [re]cedit [accedit $\mathrm{ms}$.]; ymo aliquando magis in eo vigoratur quemadmodum occulus colirio inmisso ad tempus perturbatur ut postea clarior efficiatur.

[§28] Obicitur forte vobis genus. O mira inprudentium hominum vanitas, qui de tanta laude vos vituperant, de tanta gloria diffamant, de tanto honore et honestate [non] credunt! Est verum, fratres mei, quod secundum carnem nollem vos gloriari, quia spiritus est qui vivifficat; caro autem non prodest quicquam, sed si secundum carnem vel carnalem prosapiam gloriari opporteret gloriosiores estis omnibus hominibus, vos, filii Abrahe, non ut Agareni de ansilla, sed ut filii promissionis de libera. [§29] Vos a ceteris patriarchis et prophetis amicis Dei originem trahitis, reges et principes a Deo electi vestri fuerunt. Sacerdocium leviticum a Domino institutum, quo sibi per desertum in tabernaculo et Iherosolimis in sancto templo suo [fol. 130rb] sacrifficiis et oblacionibus iugiter ministrabatur. De una tribuum vestrarum fuit. Gentem enim sanctam et regale sacerdocium vos Dominus fecit et sic nominavit ${ }^{57}$.

[§30] Replicabitur fortasse: «Omnia ista iam cessaverunt, quia omnia in figura contingebant illis ${ }^{58}$. Nunc vero, revelata veritate, nec reges nec sacerdotes habetis. Patriarchas vel prophetas ostendite, omnes enim prophete usque ad Iohannem. Ceptrum [ceptam $m s$.] de Iuda et dux de femore eius usque ad Christum ${ }^{59}$, sacerdocium Aaronicum

${ }^{54}$ Ier. 17,10: «ego Dominus scrutans cor et probans renes»; Ps. 7,10: «probator cordis et renum Deus iustus»; Apoc. 2,23: «ego sum scrutans renes et corda».

55 Quomodo in sapientem non cadit iniuria es el título que el de De constantia de Séneca adopta en manuscritos e incunables.

56 Cf. Sen. epist. 120,3: «Nihil est bonum nisi quod honestum est».

571 Petr. 2,9: «vos autem genus electum regale sacerdotium gens sancta populus adquisitionis».

581 Cor 10,11: «haec autem omnia in figura contingebant illis».

59 Gen. 49,10: «non auferetur sceptrum de Iuda et dux de femoribus eius donec veniat qui mittendus est». 
in Illo, qui est sacerdos in [e]ternum secundum ordinem Melchisedech $^{60}$, fuit termi[n]atum, et in Illum mutacione dextere Excelsi translatum ${ }^{61}$; et translato sacerdocio neccese est quod legis translatio fiat ${ }^{62}$. [§31] Quidquit ergo boni habetis, sive in spiritualibus sive in temporalibus, ab Ecclesia gencium, in qua dispersi estis, eius benignitate mendicatis».

[§32] Nescire non possumus, respondeatis, fratres, aliquid predictorum. Ingrati valde essemus si beneficia a vobis recepta non recognosceremus. Recognoscimus si quidem et laudamus et pro salute et pace nostra obsecrationes, oraciones, postulaciones, graciarum actiones specialiter pro regibus et pro hiis qui in sublimitate sunt constituti, ut sub eis quietam et tranquillam vitam agamus in omni pietate et castitate, secundum doctrinam appostoli primo omnium facimus ${ }^{63}$. [\$33] Sed quia [fol. 130va] que a vobis accepimus prius accepistis a nostris, grati esse debetis genero nostro. Legem si quidem evangelicam et appostolicam quam nos docuistis et comuniter tenemus, baptismum et cetera sacramenta ecclesiastica appostoli et evangeliste generis nostri vobis divinitus inspirati [inspiranti $\mathrm{ms}$.] tradiderunt, super quo audite appostolum vestrum ad Ephesios scribentem: «Eratis -inquit- illo in tempore sine Christo alienati a conversacione Israel et hospites testamentorum, promissionis spem non habentes et sine Deo in hoc mundo. Nunc autem in Christo Ihesu vos qui aliquando eratis longe facti estis prope in sanguine Christi; ipse enim est pax nostra que fecit utraque unum» ${ }^{64}$. [\$34] Ceterum religionem comuniter viventium Ecclesia Iudeorum Ihesosolimis prius tenuit. Illi enim fuerunt primi credentes, quorum erat cor unum et anima una, nec quisquam eorum que possidebat aliquid suum esse dice-

${ }^{60}$ Ps. 109,4: «tu es sacerdos in aeternum secundum ordinem Melchisedech».

61 Ps 76,11: «haec commutatio dexterae Excelsi».

${ }^{62}$ Hebr. 7,11-12: «si ergo consummatio per sacerdotium leviticum erat populus enim sub ipso legem accepit quid adhuc necessarium secundum ordinem Melchisedech alium surgere sacerdotem et non secundum ordinem Aaron dici translato enim sacerdotio necesse est ut et legis translatio fiat».

${ }^{63} 1 \mathrm{Tim}$. 2,1-2: «obsecro igitur primo omnium fieri obsecrationes orationes postulationes gratiarum actiones pro omnibus hominibus pro regibus et omnibus qui in sublimitate sunt ut quietam et tranquillam vitam agamus in omni pietate et castitate».

${ }^{64}$ Eph. 2,12-14. 
bat, sed erant illis omnia comunia ${ }^{65}$; ad quorum instar omnes religiones christianitatis hodie institute sunt. [\$35] Quid multis inmorer? Unum verbum Salvatoris nostri in Iohanne ad predicta sufficit: «Quoniam salus -inquit- ex Iudeis est» ${ }^{66}$. Exprobatis nobis quod regibus et principibus generis nostri caremus. Verum est. Dicite quod reges terrenos et mortales generis nostri non habemus. [§36] Sed respicite, queso, ad regem celestem et inmortalem, qui rex ${ }^{[\text {fol. } 130 \mathrm{vb}]}$ regum est et dominus dominancium, per quem reges regnant et legum conditores iuxta decernunt, qui regnat in domo Iacob in eternum et regni eius non erit finis ${ }^{67}$. Et querite ab Eo cuius filius sit. Quid enim respondebit nisi David, Abrahe et aliorum patriarcharum, regum et principum Hebreorum qui in sua genealogia ab evangelistis usque ad Mariam Virginem inclusive suo ordine inseruntur? [§37] De qua illibata genitrice sua, regina celorum, domina angelorum, quam beatam dicunt, omnes generationes. Si interrogemini cuius filia sit, quid respondebitis nisi quod de ea cantat Ecclesia: «Sicut spina rosam genuit Iudea Mariam»? ${ }^{68}$ [§38] Sinite [?] [sinectite $m s$.] iam ergo, obsecramus in Domino, ab opprobiis tanti generis, ne putantes nos confundere in Virginem eiusque Filium videamu[r] [videamus $m s$.] iniuriam irrogare, quod quantum cedat in vituperium et dampnum vestrum habens granum de intellectu poterit iudicare.

[§39] Dicitis de sacerdotibus; revera in statu gracie, quem nunc per Dei graciam vobiscum profitemur, melius circa sacerdocium nobiscum actum est quam in statu legis Moysaice. Tunc enim ad unam tribum solam, scilicet leviticam cohibebatur, [fol. 131ra] nunc vero sine differencia gentis vel tribus ad omnes equaliter extendit. Iam enim non consideratur genus sed meritum. [ $§ 40]$ Nec a principio nascentis Ecclesie deffuerunt in ea, nec modo anuerunt Domino. Defficiunt huius nacionis sacerdotes et diaconi ceterique gradus ecclesiastici, nec omnino appostolici viri dignitate et religione, quorum meritis et doctrina sancta illustrattur

${ }^{65}$ Act. 4,32: «multitudinis autem credentium erat cor et anima una nec quisquam eorum quae possidebant aliquid suum esse dicebat sed erant illis omnia communia».

${ }^{66}$ Io. 4,22 .

${ }^{67}$ Lc. 1,33: «et regnabit in domo Iacob in aeternum et regni eius non erit finis».

${ }^{68}$ Corpus Antiphonalium Officii, ed. René-Jean Hesbert (Roma: Herder, 19631979) núm. 6024: «Ad nutum domini nostrum ditantis honorem sicut spina rosam genuit Judaea Mariam». 
Ecclesia. [\$41] Et dato quod nostris demeritis exigentibus isto tempore defficerent, sufficiebat nobis ille summus et indefficiens pontiffex, qui non per sanguinem yrcorum aut vitulorum, sed per proprium sanguinem, quem de clara stirpe David traxit, introivit semel in sancta eterna redemptione inventa ${ }^{69}$.

[§42] Qui transiturus de hoc mundo ad Patrem duodecim appostolos quos sibi de mundo elegerat Ecclesie sue doctores et fundatores mundi lumina et seculi iudices dereliquit, quorum principem et capitaneum et clavigerum regni celestis Petrum, qui plus diligebat ceteris, ordinavit. Isti nempe fuerunt primi clerici, isti primi episcopi, isti fundamento Ecclesie prius Iudeorum, cuius nacionis erant, quorum patribus promissio facta fuerat, postea gentilium, qui super misericordia honoraverunt Deum, ${ }^{70}$ primos lapides iniecerunt. [\$43] [fol. 131rb] Ea propter Ecclesie Iudeorum per os propheticum dicit Spiritus Sanctus: «Pro patribus tuis nati sunt tibi filii, quia loco patriarcharum in illo genere successerunt appostoli, constituentes eos principes super omnem terram» ${ }^{71}$.

[§44] Non est pretereundus vas electionis Paulus, qui antea Saulus, qui de quibusdam ad Corintios loquens: «Hebrei -inquit- sunt? Et ego. Israelite sunt? Et ego. Semen Abrahe sunt? Et ego»; statim adiungit: «Et ministri Christi sunt? Et ego» ${ }^{72}$. Et ad Philipenses scribens, cum glorietur se circumcisum octava die ex genere Israel de tribu Beniamin originem traduxisse, magis tamen gloriatur, ut ibidem subdit, in lucrifaciendo Christum et in iusticia fidei Illius et ad cognoscendum Illum et virtutem resurrectionis eius et societatem passionis Illius ${ }^{73}$. [\$45] Iste profecto appostolus per evangelium Christi in fide vos genuit, doctor gencium in

${ }^{69}$ Hebr. 9,12: «neque per sanguinem hircorum et vitulorum sed per proprium sanguinem introivit semel in sancta aeterna redemptione inventa».

70 Rom. 15,9: «gentes autem super misericordia honorare Deum».

71 Ps. 44,17: «pro patribus tuis erunt filii tibi pones eos principes in universa terra».

722 Cor. 11,21-22.

73 Philip. 3,5: «circumcisus octava die ex genere Israhel de tribu Beniamin Hebraeus ex Hebraeis secundum legem Pharisaeus»; 3,9-10: «et arbitror ut stercora ut Christum lucri faciam et inveniar in illo non habens meam iustitiam quae ex lege est sed illam quae ex fide est Christi quae ex Deo est iustitia in fide ad agnoscendum illum et virtutem resurrectionis eius et societatem passionum illius». 
fide et veritate ${ }^{74}$. Qui ad Romanos scribens se ipsum comendat de virtute Spiritus Sancti quam habuit in virtute signorum et prodigiorum in obedienciam gencium in verbo et factis, ita [ut] ab Iherusalen per circuitum usque ad Illiricum mare repleverit Evangelium Christi ${ }^{75}$. [§46] Ibi denique promisit se profecturus in Yspaniam, quod et fecit ${ }^{76}$, [fol. 131va] ut multi sancti doctores et alii assertive tenent, et de laudibus Yspanie loquentes ystoriographi inter ceteras hanc specialiter ponunt quod Paulus appostolus in illam personaliter venerit; et sua sancta doctrina illustraverit sanctissimus Iacobus Zebedei, decus Yspanie, patronus noster, cuius reliquie apud nos divina dispensacione recondite in tanta veneracione tenentur et tanta devocione a nobis et ex ceteris nacionibus frequencius visitantur; qui in vita et in morte ibidem multos ad fidem Christi convertit. [\$47] Cuius nacionis fuerit bene scitis, vel si nescitis interrogate maiores vestros et annunciabunt vobis. Cessat ergo insultacio de deffectu sacerdotum et doctorum generis nostri in statu legis gracie, cum illis celum plenum sit, terraque de illis novas plantulas cotidie germinet et fructum multiplicem Ecclesie Dei fideique catholice subministr[e]t [subministrat $m s$.].

[§48] Unum restat quod vobis, fratres mei, ab ignaris hominibus solet achileice [?] opponi, videlicet quod Christum regem vestrum crucifixistis, ea propter indignos omni bono, omni pena dignos vos perpetuo redidisti[s]. O cecum errorem! Credunt enim quod illa benedicta passio non fuerit tante efficacie quod crucifixoribus proficere potuerit vel quod peccatum crucifixionis fuerit ita grave quod sanguine Christi purgari [fol.

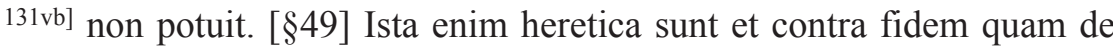
virtute passionis Christi Ecclesia Catholica predicat, et contra latissimam caritatem eius qua iustus pro iniustis voluit mori, et pro crucifixoribus exoravit, qui secundum appostolum exauditus est in omnibus pro sua

741 Tim. 2,7: «ego praedicator et apostolus veritatem dico non mentior doctor gentium in fide et veritate».

75 Rom. 15,17-19: «habeo igitur gloriam in Christo Iesu ad Deum non enim audeo aliquid loqui eorum quae per me non effecit Christus in oboedientiam gentium verbo et factis in virtute signorum et prodigiorum in virtute Spiritus Sancti ita ut ab Hierusalem per circuitum usque in Illyricum repleverim evangelium Christi».

${ }^{76}$ Rom. 15,24: «cum in Hispaniam proficisci»; 15,28: «proficiscar per vos in Hispaniam». 
reverencia ${ }^{77}$. Ista dico ad magis convincendum, dato quod manus in Christum dominum iniecissetis, ut vobis imponitur per fidem eam quam in baptismo recepisti[s], purifficata sunt corda vestra et loti ab omni peccato in sanguine suo; quanto magis quod propter infirmos! [§50] Mitius respondere potestis quod, licet aliqui pauci de natione vestra principes sacerdotum et pharisei illius temporis, qui ei invidebant et odio habebant quia eos plus ceteris arguebat, cum ministris suis Christum tradiderunt et accusaverunt et linguis suis crucifixerunt, non hoc fecerunt omnes Iudei illius temporis, quia aliarum terrarum indigene quorum erat quasi infinita multitudo per universum orbem ex precedentibus persecucionibus dispersa, pro tunc ibidem non interfuerunt nec ad diem festum omnes potuerunt convenire quamquam preceptum legale esset, quod captivitas et alie cause absencie [et] res legitime excusabant. [§51] [fol. ${ }^{132 \mathrm{ra}]} \mathrm{Nec}$ obstat quod «de omni nacione» legatur venisse ad diem festum $^{78}$, quia li[ttera] 'omni' non distribuit ibi pro singulis generum, sed pro generibus singulorum, ita quod 'de omni nacione' erant ibi 'aliqui', scilicet viri religiosi, non tamen omnes singulares illarum nacionum. [§52] In civitate enim nec per circuitum non poterat tanta multitudo recipi, nec principes terrarum apud quos tenebantur captivi eos sic permitterent adunatos exire; demum nec quotquot fuerunt civitates, incole et peregrini convenientes ad diem festum consilium, auxilium et consensum prestiterunt, cum maiores ad consilia presertim in arduis soli admitterentur, et ad istud sceleratum consilium, ut evangelica narrat ystoria, pontifices et pharisei scribe et seniores precise convenerunt ${ }^{79}$; nec de phariseis et senioribus omnes, quia non Ioseph ab Arimathia, qui discipulus erat Ihesu occultus, nec Nichodemus, qui venerat ad Ihesum nocte, isti enim non consilio mortis operam dederunt, sed sepulture eius pietate officium impleverunt. [§53] Multitudo vero plebis, que tamquam per prophetam enim habebat, vel multa turba populi, qui enim sequebatur cum mulieribus que plangebant [fol. 132rb] et lamentabantur eum, ab isto opprobrio crucifixionis exe[m]pta est, cum propter timorem eorum principes supradicti captaverunt tempus cum Iuda proditore quo modo sine

77 Hebr. 5,7: «et exauditus pro sua reverentia».

78 Act. 2,5: «erant autem in Hierusalem habitantes Iudaei viri religiosi ex omni natione quae sub caelo sunt».

79 Mt. 27,1; Mc. 15,1; Lc. 22,66. 
eis illum conprehenderent. [§54] Et si propter illos paucos totum genus Iudeorum reum illius mortis volunt constituere, dampnent totum gentilium genus quia Pilatus gentilis eum sentensiavit, gentiles milites eius illum crucifixerunt, ei illuserunt offerentes acetum et dicentes: «Si tu es rex Iudeorum salvum te fac» ${ }^{80}$. Unus illorum lancea latus eius apperuit. [§55] Ceterum post Salvatoris nostri resurrectionem et in celos assensionem, Iudeis per universum orbem fidem Christi predicantibus, quis Christum per tercentos annos et amplius in suis menbris crucifixit, appostolos et alios martires, quorum millenaria homo numerare non potest, diversis tormentorum generibus afficiendo, finaliterque morti tradendo, nisi gentiles imperatores et iudices eorum, quorum crudelem feritatem et inmanem seviciam hodie Ecclesia christianorum admiratur et reprobat? Nunquit propter istos et propter Mahumet, qui gentilis nacionis fuit, Ecclesiam gentilium, in qua nunc Deus vere colitur, dampnabimus vel reprobabimus? Absit. Quin pocius illis inmensas [fol. 132va] gracias agamus, quoniam ab Oriente in Occidentem magnum fecit nomen suum in gentibus. [§56] Essetne recta argumentacio, quia unus appostolorum proditor fuit prodicionis crimen, in totum appostolorum colegium retorquere? Vel quia unus latronum Christum bla[s]phemavit, alter qui conversus ad Ihesum dixit: «Domine, memento mei cum veneris in regnum tuum», indignus fuerit audire: "Amen dico tibi, hodie mecum eris in paradiso»? ${ }^{81}$ [\$57] Concludamus ergo cum appostolo quod omnes peccaverunt, scilicet, gentiles et Iudei, et omnes egent gloria Dei, et quod iam non est distincio Iudei et Greci, nec est Deus acceptor personarum, sed quicumque invocaverit nomen Domini salvus erit.

[§58] Replicabitur forte: Verum est quod illum peccatum non descendit in posteros nec transit ad congeneritos qua[ntu]m ad culpam nec quantum ad reatum pene eterne, quia 'anima que peccaverit', ut ait propheta, 'ipsa morietur, filius non portabit iniquitatem patris' ${ }^{82}$, etc.; sed quantum ad reatum pene temporalis aliquando Dominus punit filium pro patre, alias patrem in filio, quod ipse dixit in Exodo: 'Ego sum Dominus

${ }^{80}$ Lc. 23,36-37: «inludebant autem ei et milites accedentes et acetum offerentes illi dicentes si tu es rex Iudaeorum salvum te fac»».

${ }^{81}$ Lc. 23,42-43.

${ }^{82}$ Ez. $18,20$. 
Deus tuus, fortis, zelotes, visitans iniquitatem patrum in filios' ${ }^{83}$, etc.; [§59] et non solum filios, nepotes vel pronepotes pro peccatis parentum, sed aliquando concives et conregnicolas [fol. $132 \mathrm{vb}$ ] pro peccatis aliorum civium vel conregnicolarum, congeneritos vel contribules pro peccatis aliorum eiusdem generis vel eiusdem tribus, nisi Dominus velit aliquos de gracia speciali liberare, ut liberavit Loth ab incendio Sodomorum et Noe ab inundacione diluvii. [\$60] Quam penam illi crucifixores visi sunt contra se et filios suos postulasse, dicentes: 'Sanguis eius super nos et super filios nostros ${ }^{84}$, quod impletum est in strage, captivitate, dispersione eorum facta per Romanos †miro $\dagger$ ocisionis Christi» ${ }^{85}$.

[§61] Ex predictis clare posset elici responcio nichilominus ad auferendam contendendi occasionem. Respondeatis aliter cum sanctis doctoribus, quod peccata parentum puniuntur in filiis temporaliter si filii sunt paternorum criminum ymitatores, quod Dominus voluit in suprema auctoritate Exodi declarare dicens: «Ego sum Dominus», etc. «visitans iniquitatem» etc., «eorum», scilicet «qui oderunt me». [\$62] Et quia Iudei hodie in sua cecitate detenti, licet non omnes sunt per carnem filii eorum qui Christum crucifixerunt, omnes sunt filii ymitacione criminis, non credentes Ihesum esse Christum verum Deum, sed purum hominem deceptorem et blasphemum; quantum in se est, cotidie ipsum crucifigentes. Dignum et iustum est ut durante culpa infidelitatis durare debeat pena miserie et captivitatis. [fol. 133ra] [\$63] Set vobis, fratres mei, qui, licet essetis filii eorum secundum carnem, non estis paternorum scelerum ymitatores. Quin ymo, relicta infidelitatis tenebra, veram lucem que illuminat [omnem] ${ }^{86}$ hominem venientem in hunc mundum, scilicet Ihesum Christum dominum nostrum, Deum verum et hominem mortuum propter delicta nostra resurrexisse, propter iustifficacionem nostram,

${ }^{83}$ Ex. 20,5: «ego sum Dominus Deus tuus fortis zelotes visitans iniquitatem patrum in filiis in tertiam et quartam generationem eorum qui oderunt me».

${ }^{84}$ Mt. 27,25.

${ }^{85}$ La lectura miro es clara en el manuscrito, pero el copista seguramente transcribió el original defectuosamente (tal vez haya que suponer una mala interpretación de in rō $>$ in ratione).

86 El manuscrito grafía opp $3>$ opportet, pero es claro que debe tratarse de una mala lectura de omnem, seguramente abreviado oz en el original. $C f$. la fuente: «erat lux vera quae inluminat omnem hominem venientem in mundum» (Io. 1,9). 
cum aliis credibilibus ad salutem neccesariis, corde creditis ad iusticiam et ore confitemini ad salutem. "Que pars est [fideli] cum infidelibus, que enim participacio -inquit appostolus- iusticie cum iniquitate, aut que societas lucis ad tenebras, que autem convencio Christi ad Belial?»> ${ }^{87}$ Peccant ergo qui vos eisdem criminibus cum infidelibus involvunt, eiusdem pene participes faciunt.

[§64] Illud de neophitis non ordinandis puerile est. Hoc vobis per convicio opponunt qui nesciunt interpretacionem vel significacionem vocabuli vel nolunt diligenter attendere iura que de hac materia locuntur. Neophitus enim interpretatur 'novus' vel 'rudis in fide' vel 'nuper ad fidem conversus' et talis prohibetur ab appostolo ordinari, quia nondum instructus in hiis que fidei sunt nec probatus circa ea que religioni [fol. 133rb] christiane conveniunt, [ne] elatus forte in superbiam in iudicium incideret et in laqueum diaboli ${ }^{88}$. [\$65] «Momentaneus namque sacerdos -dicit canon- nescit humilitatem, modos personarum vel sesse contempnere. Non ieiunavit, non flevit, non se correxit, non pauperibus sua errogavit. In arroganciam, que est ruina diaboli, incidunt, qui puncto hore necdum discipuli fiunt magistri. Miserum est enim fieri magistrum qui necdum didicit esse discipulus». [§66] Et ista prohibicio comprehendit et neophitos conversos de iudaismo et conversos de gentilitate vel paganismo; ymo expressius iura in ista prohibitione loquuntur de gentilibus quam de Iudeis, ut illud: «Qui heri erat in theatro, hodie non sedeat in ecclesia; qui vespere erat in circo, hodie non ministret altario; qui dudum fuerat fautor ystrionum, hodie non sit consecrator virginum ${ }^{89}$.

872 Cor. 6,14-15.

881 Tim. 3,6: «non neophytum ne in superbia [var. superbiam] elatus in iudicium incidat diaboli»».

89 Las dos citas anteriores quedan recogidas en Decretum, dist. 48, pars 1: «Prohibentur etiam neophiti in episcopos ordinari, ut qui heri erat catecuminus, hodie non fiat episcopus, qui heri erat in teatro, hodie non sedeat in ecclesia, qui uespere erat in circo, hodie non ministret altario, qui dudum fuerat fautor istrionum, hodie non sit consecrator virginum. Causa autem huius prohibitionis est secundum Apostolum, ne elatus in superbiam tamquam religio Christiana plurimum eo egeret, incidat in ruinam diaboli. Momentaneus namque sacerdos nescit humilitatem, modos personarum, uel se contempnere; non ieiunauit, non fleuit, non se correxit, non pauperibus erogavit. In arrogantiam (quae est ruina diaboli) incidunt, qui puncto horae necdum discipuli fiunt magistri, et sicut Innocentius ait, miserum est, eum fieri magistrum, qui necdum didicit esse discipulus». 
Ista omnia, videlicet esse in teatro vel in circo vel favere ystrionibus, ludi vel supersticiones, fuerunt gentilium, non Iudeorum.

[§67] Clare hoc dicit canon Niceni Consilii: «Quoniam multa sive per neccesitatem sive ex quacumque causa contra regulam gesta sunt, ita ut homines ex vita gentili nuper adhuc cathecumini vel instructi statim ad spirituale baptisma venissent et continuo, cum baptizati sunt, [fol. 133va] etiam [et $m s$.] ad episcopatum vel presbiteratum transacti sunt, recte $\mathrm{e}[\mathrm{r}] \mathrm{go}$ visum nichil de cetero tale fieri. Nam et tempore opus est ut sit cathecuminus, et post baptismum multa probacione indiget» ${ }^{90}$.

[§68] Et de talibus neophitis Iudeorum posset intelligi illud decretum Toletani Consilii: «Qui Iudei aut hii qui ex Iudeis sunt officia publica nullathenus habeant» ${ }^{91}$, licet secundum alios posset intelligi et bene de Iudeis et famulis eorum, vel secundum alios de Iudeis et de christianis qui condam fuerunt Iudei; [ $§ 69]$ de quibus instatuit aliud Consilium Toletanum quintum: «Plurimique ex Iudeis, qui dudum ad Christianam fidem promoti sunt, nunc blasphemantes Christum non solum Iudaicos ritus perpetrasse noscuntur, sed eciam abhominandas circumsisiones exercere»; de quibus decretum est ibidem quod: «Huiuscemodi transgressores pontifficali auctoritate correcti ad cultum Christiane religionis revocentur» ${ }^{92}$.

[§70] Dicere quod de omnibus conversis ex Iudaismo illa prohibicio appostoli et canonice sanciones de hac materia loquentes debent intelligi est expositio scandalosa, themeraria, heresim sapiens, [fol. 133vb] sisma inducens, sicut ex supradicte evidenter colligi potest. [\$71] Cuius oppositum voluit beatus Ambrosius, tractans illud verbum appostoli ad Romanos Iudeo primum et Greco ${ }^{93}$ : «Iudeum -inquit- primum nomina

${ }^{90}$ Can. Nicaen. 2, recogido en Decretum dist. 48, c. 1 (con prouecti sunt en lugar de transacti sunt). Otras versiones en Ecclesiae Occidentalis Monumenta Iuris Antiquissima I, ed. Cuthbert Hamilton Turner (Oxford: Clarendon, 1899-1939) págs. 183-185, y La colección canónica hispana. vol. III: Concilios griegos y africanos, eds. Gonzalo Martínez Díez y Félix Rodríguez Barbero (Madrid: CSIC, 1982) págs. 67-68.

${ }_{91}$ Decretum, II, C. 17, q. 4, c. 31 Constituit.

92 Decretum, De cons., dist. 4, c. 94 Plerique.

${ }_{93}$ Rom. 1,16: «non enim erubesco evangelium virtus enim Dei est in salutem omni credenti Iudaeo primum et Graeco»; y Rom. 2,9-10: «tribulatio et angustia in omnem animam hominis operantis malum Iudaei primum et Graeci gloria autem et honor et pax omni operanti bonum Iudaeo primum et Graeco». 
prerrogativa Patrum, ut vel coronetur prius, vel dampnetur gravius» ${ }^{94}$, quod clare ante beatum Ambrosium sanciebat beatus Clemens, qui predicans Iudeis fidem Christi eorum gracia, ut ecclesiastica narrat ystoria, hoc ordine utebatur, quod patres eorum amicos Dei assereret et legem eorum sanctam et sacratissimam memor[aret] [memoriam $\mathrm{ms}$.]. [\$72] Primum quidem locum istos habituros astrueret, si legis sue sacramenta servarent, in hoc quod promissum Abrahe non negarent in Christo fuisse conpletum, idest, quod in semine Abrahe Deus hereditandas gentes promiserit omnes: «De fructu ventris tui ponam super sedem tuam», et quod per Ysayam confirmavit dicens quod virgo in utero conciperet et pareret filium cui nomen vocaretur Hemanuel ${ }^{95}$. [\$73] Hoc vos sinpliciter asseritis, hoc cum aliis fidei catholice articulis, non nunc noviter, sed a magnis temporibus, et plures vestrum a nativitate alicuius alterius legis vel secte penitus [fol. 134ra] ignari cum Ecclesia Sancta Catholica et Appostolica firmiter profitemini. Que ergo sufficiencia est pos[t]quam ieiunastis, postquam flevistis, postquam instructi estis, postquam probati estis ac si heri vel nudius tercius fuissetis conversi vos neophitos nominare et sub eorum regula, iure vel ordinacione vos conprehensos credere vel extimare.

[\$74] Consolamini ergo, consolamini, popule Dei ${ }^{96}$, quia non, ut vani et ignari homines dicunt, sic Sacra Scriptura, fides catholica, Ecclesia Sancta Dei abiectos et humiliatos vos reputat, sed magnos et gloriosos vos credit et predicat: «Non enim estis hospites [et] advene, sed cives

94 Ambrosiast. in Rom. 2,9 (PL 17, col. 66): «Semper Iudaeum anteponit praerogativa Patrum, ut aut coronetur primus, aut damnetur».

95 Passio sancti Clementis II.1-2 (Patres apostolici. vol. II: Clementis Romani epistulae de virginitate eiusdemque martyrium, epistulae Pseudoignatii, Ignatii martyria, fragmenta Polycarpiana, Polycarpi vita, eds. Franz Xaver von Funk y Frank DieKamP [Tübingen: Henrik Laupp, 1913] pág. 53): «Iudaeorum vero hoc ordine gratia utebatur, quod patres eorum amicos Dei adsereret et legem eorum sanctam et sacratissimam memoraret primumque locum istos apud Deum habituros adstrueret, si legis suae sacramenta servarent in eo, quod promissum Abrahae non negarent in Christo fuisse completum. quod semine Abrahae Deus haereditandas promiserit omnes gentes; et quod dixerit ad David: 'De fructu ventris tui ponem super sedem tuam [PS. 131,11]'; et quod per Esaiam confirmaverit, quod 'virgo in utero conciperet et pareret filium, et vocaretur nomen eius Emmanuel' [Is. 7,14: «ecce virgo concipiet et pariet filium et vocabitis nomen eius Emmanuhel»].

${ }^{96}$ Is. 40,1: «consolamini consolamini populus meus dicit Deus vester». 
sanctorum et domestici Dei, superhedifficati super fundamentum appostolorum et prophetarum, ipso sumo angulari lapide Christo Ihesu, in quo omnis hedifficatio constructa crescit in templum sanctum in Domino» ${ }^{97}$. [\$75] Cotidie nempe cantat Ecclesia quod Simeon iustus de Christo domino nostro, dum illum in templo in ulnas suas reciperet, spiritu prophetico decretavit Christum lumen ad revelacionem gencium et gloriam plebis sue Israel ${ }^{98}$. [§76] Rursum vestrum eundem Paulum [fol. 134rb] pusillanimitatem vestram consolantem audite: «Nunquit repulit Dominus populum suum? Absit. Nam et ego -inquit- israelita sum, ex semine Abrahe de tribu Beniamini. Non repulit Deus plebem suam quam prescivit» ${ }^{99}$; et infra de eodem populo Iudeorum loquens: «Nunquid sic offenderunt ut caderent? Absit; sed illorum delicto salus est gentibus, ut illos emulentur, quod si delictum eorum divicie sunt mundi et diminucio eorum divicie gencium, quanto magis plenitudo eorum!» ${ }^{100}$, et subdit: «Si enim amissio eorum reconciliacio est mundi, que assumpcio nisi vita ex mortuis? Quod si delibacio est sancta, et massa; et si radix sancta, et rami. Quod si aliqui ex ramis fracti sunt, tu autem, cum oleaster esses, insertus es in illis, et socius radicis et pinguedinis olive factus es. Noli gloriari adversum ramos, quod si gloriaris non tu radicem portas sed radix te. Dicis: fracti sunt rami ut ego inserar. Bene: propter incredulitatem fracti sunt rami, tu autem fide stas. Noli altum sapere, sed time. Si enim Deus naturalibus ramis non pepersit, forte nec tibi parcat. Vide ergo bonitatem et severitatem Dei: in eos quidem qui ceciderunt, [fol. 134va] severitatem; in te autem bonitatem Dei, si permanseris in bonitate, alioquin et tu excideris. Sed et illi, si non permanserint in [in]credulitate inserentur; potens est enim Deus inserere illos. Nam si tu ex naturali excisus es oleastro et contra naturam insertus et in bonam olivam, quanto magis hii qui secundum naturam inserentur sue olive» ${ }^{101}$. [\$77] Ecce quam magniffice vos comendat et blande consolatur appostolus: magnifice comendat in eo quod patres vestros dicit delibationem sanctam et radicem sanctam et vos massam sanctam et ramos sanctos; blande conso-

\footnotetext{
97 Eph. 2,19-21.

98 Lc. 2,25-32.

99 Rom. 11,1-2.

100 Rom. 11,11-12.

101 Rom. 11,15-24.
} 
latur in eo quod ruina[m] generis vestri non dicit universalem esse, ita quod sit omnium de illo genere et illorum quorum fuit, quod non fuit irreparabilis nec inutilis, sed reparabilis in se et toti mundo utilis. Que appostolus scripsit, ego vobis transcribo ut calumniantibus habeatis quid respondere possitis. [\$78] Non in carne vel in nobilitate carnalis generis gloriam queratis, quia idem appostolus sepe dicit: «Qui gloriatur in Domino glorietur» ${ }^{102}$, et: «Absit michi gloriari nisi in cruce Domini nostri Ihesu Christi» ${ }^{103}$; et alibi: «Libenter gloriabor in infirmitatibus [fol. 134vb] meis ut inhabitet in me virtus Christi, propter quod placeo mihi in infirmitatibus meis, in contumeliis, in neccesitatibus, in persecucionibus, in angustiis pro Christo» ${ }^{104}$.

[§79] Videtis ergo, dilectissimi, quomodo tota Sancta Scriptura exemplo Christi et sanctorum ad pacienciam vos tam efficaciter invitat et tam dulciter in tribulacionibus consolatur. Ad huc vester episcopus Iacobus illud sumatim prestingit si quasi vos aloquens in canonica sua ait: «Exemplum accipite, fratres, exitus mali et longanimitatis et laboris et pacienciae prophetas qui locuti sunt in nomine Domini. Ecce beatificamus eos qui sustinuerunt sufferenciam. Iob audistis et finem Domini vidisti[s] quoniam misericors est Dominus et miserator» ${ }^{105}$.

[§80] Convertimini ergo ad Illum in toto corde vestro et in tota anima vestra et invocate nomen eius in Ihesu Christo Filio suo unico, Domino nostro, in quo nec circumsisio aliquid valet nec prepucium, sed nova creatura ${ }^{106}$. Reformamini spiritu mentis vestre ${ }^{107}$, exuent[e]s [exuentis $m s$.] veterem hominem cum actibus suis et induentes [fol. 135ra] novum hominem ${ }^{108}$, qui secundum Deum creatus est in iusticia et sanctitate veritatis, dicent[e]s [dicentis $m s$.] cum vestro Ysaya: «Vetus error abiit;

\footnotetext{
1021 Cor. 1,31; 2 Cor. 10,17.

103 Gal. 6,14.

1042 Cor. 12,9-10.

105 Iac. 5,10-11.

106 Gal. 6,15: «neque circumcisio aliquid valet neque praeputium sed nova crea-

107 Eph. 4,23: «renovamini autem spiritu mentis vestrae».

108 Colos. 3,9-10: «nolite mentiri invicem expoliantes vos veterem hominem cum actibus eius et induentes novum eum qui renovatur in agnitionem secundum imaginem eius qui creavit eum».
} tura». 
servabis pacem; pacem quia in te, Domine, speravimus» ${ }^{109}$. Quod si feceritis, audiet Dominus et miserebitur vestri. Dominus erit adiutor vester, convertet planctum vestrum in gaudium, concidet sacum vestrum et circumdabit vos leticia ${ }^{110}$.

[§81] Hec vobis scribo, fratres, non in sublimitate sermonis nec in perssuasilibus humane sapiencie verbis, sed in conpassione animi, utens simplici Sacre Scripture eloquio, ut per pacienciam et consolacionem Scripturarum spem habeatis. Deus autem paciencie et solacii det vobis id ipsum sapere ${ }^{111}$, conteratque Sathanam [sub pedibus] vestris velociter. Gracia Domini nostri Ihesu Christi vobiscum ${ }^{112}$. Amen.

[§82] CONCLUSIONES VEL SENTENCIE QUE AD LAUDEM ET GLORIAM DOMINI NOSTRI IHESU Christi EIUSQUe beATISSIME Matris VIRGINIS MaRIE CONSOLACIONEMQUE VESTRAM ET ADVERSARIORUM CONFUTACIONEM EX PREDICTIS POSSUNT ELICI CORRELARIE ${ }^{113}$ VEL INCIDENTER. SUNT QUE SECUNTUR.

[fol. 135rb] Prima conclusio. Dicere quod Christus dominus noster et beatissima eius mater Virgo Maria non fuerunt de genere Iudeorum est hereticum et qui hoc pertinaciter asserit est hereticus.

Secunda conclusio. Dicere quod omnes descendentes de genere Iudeorum sunt innobiles vel non generosi est hereticum; qui hoc pertinaciter asserit est hereticus.

Tercia conclusio. Dicere quod omnes conversi ex circumcisione sunt in statu dampnacionis vel quod sunt inhabiles ad graciam et gloriam est hereticum, et qui hoc pertinaciter asserit est hereticus.

109 Is. 26,3 .

110 Ps. 29,12: «convertisti planctum meum in gaudium mihi concidisti saccum meum et ciucumdedisti me laetitia».

111 Rom. 15,5: «Deus autem patientiae et solacii det vobis id ipsum sapere in alterutrum secundum Iesum Christum».

112 Rom. 16,20: «Deus autem pacis conteret Satanan sub pedibus vestris velociter gratia Domini nostri Iesu Christi vobiscum».

113 El adverbio correlarie, no muy utilizado, aparece también en la Responsio apologitica (véase el ítem [9] del manuscrito, fol. 169vb). Se documenta desde Buridán a Pico della Mirandola, con el sentido de 'como corolario'; cf. René Hoven, Lexique de la prose latine de la renaissance (Leiden: Brill, 1994) s.v. 
Quarta conclusio. Dicere quod omnes tales sunt indigni dignitatibus ecclesiasticis et temporalibus, vel inhabiles ad eas, est scandalosum, temerarium, et si ex premissis illis hereticis hoc concludatur eciam erit hereticum; qui hoc pertinaciter asserit est hereticus.

Quinta conclusio. Dicere quod per conversionem ad fidem Christi sit distinctio Iudei et gentili est hereticum, et qui hoc pertinaciter asserit est hereticus, et qui illam distincionem electione desiderat vel de facto studios[e] [studioso $m s$.] procurat est cismaticus.

Sexta conclusio. Quicumque conversos ad Christum habet exosos quia de genere Iudeorum sunt extra caritatem est et in statu dampnationis.

Septima conclusio. Quicum[que] illos spernit quia de illo genere sunt Christum spernit et quantum in se est inimicum eius se constituit.

Incitativus [?] ${ }^{114}$. Principes ecclesiastici et temporales tenentur secundum utriusque iuris et regulas contra predictos hereticos, iniquos homines et blasphemos procedere et illos condigna animadversione punire, quod si non faciant mortaliter peccant.

\section{TRADUCCIÓN}

[§1] Queréis saber, carísimos hermanos en Cristo, qué me parece esta nueva clase de conflicto. Y yo digo que no es nuevo, sino antiguo; porque vienen a renovarse las antiguas persecuciones. Pues en virtud del juicio de Dios, oculto aunque no injusto, el viejo enemigo trata de derribar aquellos dos muros que la piedra angular de Cristo Nuestro Señor había unido en sí mismo ${ }^{115} ;[\S 2]$ intenta aquel, por su parte, separarlos

114 En el manuscrito se lee la abreviatura Inci. ${ }^{u s}$ o Inci. ${ }^{n s}$, que muy dubitativamente hemos interpretado como Incitativus (o tal vez Incitans).

115 Sobre la base de Eph. 2,19-21 y Ps. 117,2, la exégesis patrística y medieval estableció que Cristo era la piedra angular que procuró la unión, en una sola Iglesia, de los dos muros, el de los judíos y el de la gentilidad. $C f$. San Jerónimo: «In caput connenctens duos parietes: unum de circumcisione, alium de praeputio, in uno novo homine, hoc est in semetipso» (in psalm. 117, PL 26, col. 1257); véase Gerhart B. LADNER, «The Symbolism of the Biblical Corner Stone in the Medieval West», Images and Ideas in the Middle Ages. Selected Studies in History and Art (Roma: Edizioni di Storia e Letteratura, 1983) vol. I, págs. 171-196 para muchos más ejemplos. La imagen aparece en 
y rechazarlos de sí, y viendo cómo nosotros, a quienes considerasteis como circuncisos ${ }^{116}$, quedábamos libres del yugo de su servidumbre, siendo así que antes nos poseía como esclavos, no puede tolerar que nosotros y nuestros hijos propaguemos insistentemente la fe de Cristo, por medio de la cual se accede al cielo, de donde él mismo fue arrojado; y, tocado por el dolor, trata de destruir en nosotros, mediante la crueldad de las persecuciones, los cimientos de la fe que aquel nuestro arquitecto hizo sólidos con su purísima sangre.

[§3] Os ruego, por tanto, hermanos, que no desfallezcáis en la tribulación, sino que vistáis la armadura de la fe y resistáis a tan grande adversario, fuertes en la fe. El enemigo es débil, no puede vencer más que a quien así lo desea; es muy astuto, pero solo en tanto que así lo tornáis [?]. Pero, sostenidos por el favor divino, convertid esta persecución, que prepara una ocasión de ruina o escándalo, en materia de virtud o mérito. [§4] A menudo le sucede a este tirano, a quien nuestro Salvador llama príncipe de este mundo ${ }^{117}$, que, si llega a luchar contra un cristiano humilde, aunque fuerte, cree decir [¿vencer?] y avanza, y así, engañado por su propio deseo, retrocede confuso, huye del vencedor, vencido [?], y cesa en la persecución.

[§5] Lo único que temo es que, acostumbrados a la prosperidad mundana, y no habituados a las adversidades, os veáis doblegados ante los males presentes. Lejos esté de sucederos esto a vosotros, amadísimos, que habéis leído en la sagrada historia del Antiguo Testamento cuántos males sufrieron vuestros padres en Egipto, de manos del Faraón, y cuántos en el desierto cuando los conducía Moisés. [§6] De ellos, hubo quienes irritaron al Señor con su impaciencia y, cayendo allí mismo, no alcanzaron la tierra deseada; los constantes y aquellos que ignoraron con confianza el flagelo del Señor se hicieron dignos del sublime fruto de la tierra e ingresaron en el descanso del Señor. Después de todo esto, co-

Oropesa, Luz para el conocimiento \$32; o en Torquemada, Tratado contra los madianitas $\$ 15.4$.

116 Cf. Oropesa, Luz para el conocimiento \$28, pág. 357: «Pues la Iglesia tiene dos senos apreciables que son las dos clases de predicadores que subliman y exaltan su santísima fe: uno de la incircuncisión de los gentiles y otro de la circuncisión de los judíos».

117 Cf. Torquemada, Tratado contra los madianitas $§ 6.7$, pág. 278: «apenas entrado en el campo de batalla de este mundo para pelear contra el príncipe de este mundo». 
nocéis mejor que yo cuántos ataques hostiles recibieron estos mismos padres vuestros de los filisteos y otras naciones bárbaras en tiempos de los Jueces y los Reyes, casi sin interrupción hasta el cautiverio de Babilonia, exceptuando solo aquella pacífica época de Salomón. [§7] Resultaría muy tedioso escribir todas las ofensas que les infligieron las naciones vecinas cuando, reinando los persas, regresaron de la cautividad y reedificaron el Templo; o todo lo que los griegos hicieron después, bajo Antíoco; o finalmente los romanos, cuando ya la verdad había sido revelada. [§8] Las persecuciones, por tanto, no son ajenas a nuestra nación, sino más bien características de nuestra estirpe. Y si sobrevienen no han de asombrar como si sucediese algo nuevo, sino que más bien Dios quiere que, para que el daño sea menor, nos encuentren habituados, prevenidos y preparados. [\$9] Tal y como dice el dicho del Sabio: «Él ofende a quien ama, y se complace en él como un padre en su hijo»; en su Hijo unigénito, digo yo, igual a Él, eterno como Él y consustancial con Él, quien, enviado desde el trono real para que reuniera a los hijos dispersos de Abraham, unió en sí la carne emanada de aquella semilla. [\$10] Así pues, y al igual que el Verbo se hizo carne y habitó entre nosotros, no quiso Él que se viese envuelto en las riquezas, placeres u honores de nuestro siglo, sino que fuese para nosotros ejemplo de humildad, pobreza y paciencia en tanto que tuvo trato con los hombres en la tierra, y finalmente lo entregó a un acerbo padecimiento y una ignominiosa muerte por todos nosotros.

[§11] De manera que, hermanos míos carísimos, si sufrís la rapiña de vuestros bienes, ¿qué otra cosa significa esto sino que vuestro Padre celestial quiere apartaros de los fuegos de la avaricia y la inútil ansia de riquezas, y situaros junto al Hijo en su serena pobreza? Si, por lo demás, por respetar la justicia de nuestro rey, sufrís de parte de quienes desobedecen y se rebelan contra él hambre, sed, desnudez, muertes y torturas (creo que es así, según oigo), bienaventurados sois. [§12] «Bienaventurados -dice el Salvador- los que padecen persecución por justicia», y en esto os igualáis más verdaderamente al propio Salvador Cristo nuestro Señor, guardando aquello que vuestro apóstol Pedro exhorta en su cánonica: «Y pues Cristo padeció en la carne -dice-, armaos también del mismo pensamiento»; seguros de que, si sufrís con Él, también reinaréis con Él y, si lo acompañáis en sus pasiones, tendréis parte también 
de sus consolaciones. Dios quiere, en consecuencia, que vosotros, bajo su mano omnipotente, seáis humillados junto con su Hijo en este mundo transitorio, para que eternamente seáis enaltecidos junto a Él en la tierra de los vivos. [§13] Mucho os ama, pues, cuando os hace semejantes a su único Hijo en la vida, semejantes en su medida en el conocimiento, del todo iguales en la recompensa. Considerad, amados, dónde están ahora los apóstoles, vuestros hermanos, para quienes el propio Hijo de Dios dispuso el reino de su Padre por haberse conducido como sus émulos perfectos tanto en la vida como en el padecimiento, para que en su reino coman y beban sobre su mesa, destinados a sentarse en el juicio final y temible sobre doce sitiales, para juzgar a las doce tribus de Israel. [§14] Todo el mundo alaba tanto a los mártires como a los demás santos, quienes, aunque sufrieron tormentos entre los hombres, gozan por siempre de una esperanza inmortal. Por tanto, no tenéis una causa justa para quejaros porque Dios os flagela, sino más bien para darle las gracias porque os enmienda como a hijos y, como el oro en la hornaza, prueba que sois sus elegidos.

[§15] Algunos de los vuestros responden con suma aspereza: «Es grato soportar esta repentina persecución que nuestro adversario ha promovido en esta época, pues creemos que, gracias a la misericordia de Dios, y con ayuda de los servidores de rey, no habrá de durar mucho, sino que habrá de terminar en breve. Pero ¿quién podría tolerar con paciencia los continuos ultrajes de los que nos vituperan? [§16] De una parte, nos insultan los judíos, diciendo que nos hemos desviado del camino recto y hemos apostatado de la religión verdadera, y nos reputan por descarriados, apóstatas, no conversos sino adversos y perversos, y, como pueden hacerlo de forma impune, así nos llaman públicamente. [§17] Los cristianos, por otro lado, que deberían confortarnos y consolarnos, por cuyas prédicas aceptamos la fe ortodoxa, mediante la que nos unimos a ellos y espiritualmente nos convertimos en un solo cuerpo, creyendo firmemente junto a ellos y teniendo una fe sincera en un Dios uno y trino, y guardando y observando cotidianamente las mismas creencias, los mismos sacramentos, y unos ritos que no son otros que los que de ellos aprendimos y los que la Santa Iglesia Romana, Católica y Apostólica observa y aprueba, murmuran contra nosotros, nos denigran cantando y diciendo palabras y maldiciones injuriosas, burlándose y rién- 
dose de nosotros, por separado y conjuntamente, lo cual hacen por divertirse y sin otro motivo ${ }^{118}$. Todo y por todas partes son zozobras para nosotros. Que Dios lo vea y juzgue, y que su piedad no nos abandone».

[§18] Veo, oh dolor, hermanos, que se abre la puerta de un gran escándalo, pero ¡ay del hombre por quien se produce escándalo!; y temo que a quienes escandalizan no les sobrevenga el mal con el que nuestro Redentor amenaza en el Evangelio: «Quien escandalice a uno de estos pequeñuelos que creen en mí, más le valiera que le colgasen al cuello una piedra de molino de asno y le hundieran en el fondo del mar» ${ }^{119}$, y la maldición del apóstol, que dice: «Ojalá se descuartizase a quienes os perturban». [\$19] Aunque vosotros, que habéis sido educados para rogar por quienes os persiguen y vencer al mal con el bien, ¿qué otra cosa convendrá que hagáis sino suplicar al Padre, como nuestro Maestro cuando fue torturado y clavado a la cruz, y decir: «Padre, perdónalos, porque no saben lo que hacen»? [\$20] Pero puesto que no estáis tan preparados para que esta doctrina de perfección os baste, si está en mi mano amputaré de vosotros, a quienes ahora hablo, la materia del escándalo pasivo ${ }^{120}$, o al menos, si no llego a tanto, la atenuaré, para que nos os anegue ni engulla la tormenta de la tribulación ni el pozo de la tristeza [cargue] sobre vosotros su boca. [\$21] Para conseguirlo bastaría lo que vuestro apóstol Santiago de Jerusalén dice escribiendo en aquel tiempo a las doce tribus de la dispersión, que habían sufrido cosas semejantes: «Apreciad, hermanos míos, todo el gozo de caer en diversas tentaciones, entendiendo que la prueba de vuestra fe engendra la paciencia. La pa-

118 Cf. ORopesa, Luz para el conocimiento §2, págs. 89-90: «presumen de odiar a estas personas y se deleitan en zaherirles todo lo posible con ultrajes e insultos, se afanan en acursarlos de apóstatas, de cristianos fingidos y judíos ocultos, y no se guardan de gritarles despectivamente con voz soberbia lo que suelen decir con más frecuencia que todo lo demás: tornadizos y marranos»; y Díaz de Montalvo, La causa conversa, pág. 147, nota 1, para las prohibiciones de insultar o motejar a los judíos, repetidas desde el Fuero Real hasta distintas ordenanzas del siglo XV.

119 Mt. 18,6. Cf. Díaz de Montalvo, La causa conversa §52, y Oropesa, Luz para el conocimiento §4, pág. 102.

120 Para 'escándalo pasivo', basta acudir al diccionario del a RAE: «Ruina espiritual o pecado en que cae el prójimo por ocasión del dicho o hecho de otro»; el bagaje teológico que en la época permitía entender el concepto comenzaba sin duda por Santo Tomás, Summa theolog. II-II', qu. 43, art. 1. 
ciencia obtiene una obra perfecta, para que seáis perfectos e íntegros, sin que os falte cosa alguna».

[§22] No obstante, y teniendo en cuenta, como atestigua el Filósofo en los Morales, que los enunciados más universales son los más inútiles y de menor eficacia, conviene descender al nivel más bajo y conocer la causa específica de la enfermedad, para no ignorar su remedio; interesa, pues, saber cuáles son estas ignominias de las que se os acusa con tanta acritud. [§23] Si el más cristiano os contradice: «Es mejor sentir alegría que tristeza, siguiendo el ejemplo de aquellos apóstoles que salieron de la presencia del sanedrín contentos, porque se habían hecho dignos de padecer ultrajes por el nombre de Jesús», aunque no ha de presumirse que un cristiano vitupere en nosotros lo que cree merecedor de la mayor alabanza en sí mismo; si, en fin, y ojalá no sea así, alguien hace esto en su ignorancia, os está llamando discípulos de Cristo, pero él se erige en imitador de Nerón, de Domiciano, de Diocleciano, de Maximiano, de Juliano el Apóstata y de sus esbirros, que hicieron causa para ejercer su crueldad con los santos de Dios, igual que hoy hacen los mahometanos. [§24] Si se nos reprochan a nosotros, señaladamente más que a los demás, la avaricia, la soberbia, la envidia y los demás pecados que son comunes a prácticamente todos los hombres, examinaos a vosotros mismos, amadísimos, y si encontráis en vosotros tales pecados, el remedio será abstenerse de ellos y expulsar de vuestras mentes los deseos carnales que militan contra el alma, y hacer siembra con los granos de las virtudes para que den un fruto céntuplo. [\$25] Pues si lográis trocar la soberbia en humildad, la avaricia en generosidad, la lujuria en castidad, la envidia en caridad, el vituperio de los maledicentes se habrá convertido en paternal reprensión. Que el calumniador que perdió la virtud se entristezca: tú alégrate, porque la recuperaste; que solloce quien se mantiene como enemigo de Dios: regocíjate tú, porque te has convertido en su amigo. Bueno fue, al fin y al cabo, el vituperio que te ha cubierto de tan grandes bienes. [\$26] Y si los antedichos pecados que os imputan no se hallan en vosotros, no recibís ningún daño, y el difamador contumelioso no puede perjudicaros de ningún modo. Decid, cualquiera de vosotros, con el apóstol: «Esta es mi gloria, el testimonio de mi conciencia, y no me importa lo que digan estos hombres que se fijan exclusivamente en lo exterior, porque no nos corresponde a nosotros juzgar lo que 
dice cada cual, y a mí, verdaderamente, solo puede juzgarme Aquel que escruta las entrañas y los corazones». [\$27] Esto es lo que quiere la escuela de los estoicos, que defiende que el sabio no puede recibir ultrajes, porque no reputa que nada sea malo si no es algo indecente o un vicio, ni que nada sea bueno si no es algo honesto o una virtud; en su búsqueda de la verdad [?], el sabio o virtuoso, si durante un momento es turbado por un ultraje o algún otro infortunio, nunca sin embargo llega a angustiarse, porque nunca se aparta del bien de la razón; es más, algunas veces sale fortalecido, de igual manera que el ojo, cuando recibe el colirio, se nubla por un momento para después ver con más claridad.

[\$28] Tal vez se os echa en cara el linaje. ¡Oh, asombrosa vanidad de hombres imprudentes, que os vituperan por lo que es un tan gran mérito, que os difaman por tan grande gloria, que [des]creen de tan gran honor y honra! Es verdad, hermanos míos, que no quiero que os gloriéis de la carne, porque el que da vida es el espíritu; la carne en nada beneficia, pero si importase ensalzar la carne o la prosapia carnal, los más gloriosos de todos los hombres seríais vosotros, los hijos de Abrahán, que sois hijos, no de una sierva, como los agarenos, sino, en tanto que hijos de la promisión, de una mujer libre. [§29] Vosotros tenéis origen en los demás patriarcas y profetas amigos de Dios; vuestros reyes y príncipes fueron elegidos por Dios. El sacerdocio levítico fue instituido por el Señor para que por el desierto, en el tabernáculo, y en Jerusalén, en su santo Templo, se le oficiasen de continuo sacrificios y ofrendas. Y fue de una de vuestras tribus. El Señor hizo que fuéseis una raza santa e instituyó en vosotros el sacerdocio real, y así lo llamó.

[§30] A esto se replicará quizás: «Todas estas cosas ya pasaron, porque todas estas cosas les sucedieron a ellos en sentido alegórico. Ahora, en cambio, revelada ya la verdad, no tenéis ni reyes ni sacerdotes. Mostradnos los patriarcas y los profetas, pues todos son profetas hasta Juan. El cetro de Judá y el jefe de su linaje hasta Cristo, el sacerdocio de Aarón, han concluido en Él, que es el sacerdote para siempre según el orden Melquisedec, y a Él se ha traspasado, con la mudanza de la diestra del Excelso; y, mudado el sacerdocio, es forzoso que haya una mudanza de la ley. [\$31] Todo lo que de bueno tenéis, pues, ya sea en lo espiritual o en lo temporal, lo mendigáis con su benignidad de la Iglesia de los gentiles, en la que estáis dispersos». 
[§32] No podemos ignorar, deberíais responder, hermanos, nada de lo dicho. Seríamos muy ingratos si no reconociésemos los beneficios que hemos recibido de vosotros. Claro está que los reconocemos y los apreciamos, y por nuestra salvación y nuestra paz dirigimos antes de nada peticiones, oraciones, súplicas y acciones de gracias, especialmente por los reyes y por quienes están constituidos en dignidad, para que bajo ellos llevemos una vida tranquila en toda piedad y castidad, según la doctrina del apóstol. [§33] Pero puesto que lo que recibimos de vosotros lo recibisteis primero de nosotros, debéis estar agradecidos a nuestro linaje. Es evidente que la ley evangélica y apostólica que nos enseñasteis y que tenemos en común, el bautismo y los demás sacramentos eclesiásticos os los legaron los apóstoles y evangelistas de nuestro linaje, por inspiración divina, sobre lo cual escuchad lo que escribe a los Efesios vuestro apóstol: «Estabais - dice- en aquel tiempo, sin Cristo, separados de la comunicación con Israel, y huéspedes de los testamentos, sin tener esperanza de la promesa y sin Dios en este mundo. Pero ahora en Cristo, vosotros que en otro tiempo estabais lejos os habéis acercado en la sangre de Jesucristo; Él es nuestra paz, la que de dos ha hecho uno». [§34] Por lo demás, la primera Iglesia que tuvo la religión en una vida de comunidad fue la de los judíos de Jerusalén. Ellos fueron los primeros creyentes que compartieron un solo corazón y una sola alma, y ninguno de ellos decía que poseía cosa alguna, sino que lo tenían todo en común; a semejanza suya se instituyeron todas las religiones de la cristiandad actual. [§35] ¿Para qué he de extenderme más? Una sola palabra de nuestro Salvador, en San Juan, bastará sobre lo dicho: «Porque la salvación -dice- viene de los judíos». Nos echáis en cara que carecemos de reyes y príncipes de nuestra estirpe. Es cierto. Decís que no tenemos reyes terrenales y mortales de nuestra estirpe. [§36] Pero poned la atención, os lo ruego, en el rey celestial e inmortal, que es rey de reyes y señor de señores, por quien los reyes reinan y los legisladores asimismo decretan, que reina en la casa de Jacob por la eternidad y cuyo reino no tendrá fin. Y preguntadle a Él de quién es hijo. ¿Qué responderá, sino que de David, de Abrahán y de otros patriarcas, reyes y príncipes hebreos que son dispuestos en orden por los evangelistas en su genealogía, hasta llegar a la Virgen María? [\$37] De esta inmaculada progenitora suya, reina de los cielos, señora de los ángeles, a la que llaman beata, [proceden] todas las generaciones. Y si se os pregunta de quién es ella hija, 
¿qué responderéis sino aquello que de ella canta la Iglesia: «Como la espina a la rosa, así Judea engendró a María»? ${ }^{121}$ [§38] Cesad [?] ya, por consiguiente, os lo rogamos por Dios, de ultrajar a tan gran estirpe, para que no parezca que, creyéndonos identificados con la Virgen y su Hijo, queremos injuriaros, porque cuánto resulta esto en vituperio y daño vuestro es algo que quien tenga una pizca de inteligencia podrá juzgarlo.

[§39] Decís sobre los sacerdotes. Desde luego, en el estado de gracia que ahora profesamos con vosotros, por la gracia de Dios, en lo tocante al sacerdocio se ha actuado mejor con nosotros que en el estado de la ley mosaica. Entonces [el sacerdocio] se reservaba para una única tribu, la de Leví, mientras que ahora se extiende por igual a todos, sin diferencia de raza o tribu. No se tiene en consideración ya el linaje, sino el mérito. [§40] No faltaron en ella nada más nacer la Iglesia, y no solo dieron su consentimiento a Dios. Faltan sacerdotes de esta nación y diáconos y los demás grados eclesiásticos, no así hombres apostólicos en dignidad y religión, cuyos méritos y doctrina iluminan la Iglesia. [§41] Y por más que en este tiempo no haya, por exigirlo así nuestros pecados, nos basta el sumo y eterno pontífice, que no entró de una vez por todas en el santuario, conseguida la redención eterna, por la sangre de los machos cabríos o los becerros, sino por su propia sangre, que heredó de la clara estirpe de David.

[§42] Él, cuando iba a pasar de este mundo al Padre, nos dejó a los doce apóstoles que había elegido para sí de este mundo como doctores y fundadores de su Iglesia, y como luces del mundo y jueces del siglo; al primero de los cuales, Pedro, a quien amaba más que a los demás, colocó como guía y portador de las llaves del reino celeste. Ellos fueron ciertamente los primeros clérigos, los primeros obispos, ellos pusieron las primeras piedras en el cimiento de la Iglesia, que inicialmente fue de los judíos, a cuya estirpe pertenecían y a cuyos padres se había hecho la promesa, y después de los gentiles, que honraron a Dios en su misericordia. [§43] Por ello a la Iglesia de los judíos le dice el Espíritu Santo por boca profética: «En lugar de tus padres te han nacido hijos, porque

${ }^{121}$ Díaz de Montalvo, La causa conversa $§ 19$, pág. 164: «No pueden negar que el pueblo del que proviene nuestra Redención, la Virgen santísima, madre del Salvador, y sus santos apóstoles, mártires y confesores, por quienes fue fundada la Iglesia del Señor, es 'el más excelso de todos los pueblos que el Señor ha creado en honor, nombre y gloria'». 
en lugar de los patriarcas de esa estirpe fueron sucesores los apóstoles, constituyéndolos a ellos príncipes sobre toda la tierra».

[§44] No ha de olvidarse al vaso de elección, Pablo, que antes fue Saulo, que hablando a los Corintios de ciertos hombres: «¿Son hebreos? -dice-. Yo también. ¿Son israelitas? Yo también. ¿Son la semilla de Abrahán? Yo también»; y añade a continuación: «Y son ministros de Cristo? Yo también» ${ }^{122}$. Y escribiendo a los Filipenses, aunque se gloria de haber sido circuncidado en el octavo día y de tener origen en la raza de Israel, en la tribu de Benjamín, sin embargo más se gloria, como allí mismo añade, de tener como ganancia a Cristo en la justicia de su fe, y de tener la posibilidad de conocerlo a Él, el poder de su resurrección y la participación de su padecimiento ${ }^{123}$. [§45] Este apóstol, ciertamente, por medio del Evangelio de Cristo os creó en la fe, como doctor de los gentiles en fe y verdad. Escribiendo a los Romanos, él mismo se gloria del poder del Espíritu Santo que recibió por el poder de signos y prodigios para la obediencia de los gentiles de palabra y hecho, de manera que todo el recorrido desde Jerusalén hasta el mar Ilírico lo llenó con el Evangelio de Cristo. [§46] Finalmente, allí mismo prometió que iría a España, lo que también cumplió, tal y como aseguran muchos santos doctores y otros, y los historiógrafos, cuando tratan de las alabanzas de Hispania, mencionan especialmente, entre otras cosas, que el apóstol Pablo llegó personalmente a ella; y que la engalanó con su santa doctrina el santísimo Santiago Zebedeo, gloria de España, nuestro patrono, cuyas reliquias se conservan con mucha veneración entre nosotros en lugar sagrado, por divina dispensa, y son visitadas frecuentemente por nosotros y el resto de las naciones con mucha devoción, y quien, en su vida y en su muerte, convirtió a muchos a la fe de Cristo ${ }^{124}$. [\$47] Bien sabéis

$122 C f$. Torquemada, Tratado contra los madianitas $\$ 7.2$, y Cartagena, Defensorium II.1.2.

123 Cf. Cartagena, Defensorium II.1.8.

124 Aunque el culto al apóstol Santiago era propio de todo el ámbito hispano, puede recordarse su importancia en el entorno de Alfonso de Cartagena, que no en vano fue deán de la catedral de Santiago. Como es sabido, uno de sus discípulos, Diego Rodríguez de Almela, compuso una Compilación de los milagros de Santiago. Véase Luis Fernández Gallardo, «Tradiciones jacobeas en la Castilla del siglo XV: Intertextualidades (De Vicente de Beauvais a Rodríguez de Almela)», Revista de Literatura Medieval 28 (2016) págs. 177-202. 
de qué estirpe era este, y si no lo sabéis preguntad a vuestros mayores y os lo dirán. Cesa, pues, el insulto sobre la falta de sacerdotes y doctores de nuestra raza en el estado de la ley de gracia, cuando el cielo está lleno de ellos, y la tierra diariamente hace crecer a partir de ellos nuevas plantas y proporciona el fruto múltiple a la Iglesia de Dios y de la fe católica.

[§48] Solo resta una cosa, hermanos míos, que suele ser argumentada taimadamente [?] ${ }^{125}$ por hombres ignorantes, a saber: que crucificasteis a vuestro rey Cristo, y que por esa razón os hicisteis perpetuamente indignos de todo bien y merecedores de todas las penas. ¡Oh, ciego error! Creen que aquella bendita Pasión no fue de tanta eficacia como para que pudiese salvar a los que lo crucificaron, o que el pecado de la crucifixión fue tan grave que no pudo limpiarlo la sangre de Cristo. [\$49] Todo esto es herético, y va contra la fe que la Iglesia Católica predica sobre la fuerza de la Pasión de Cristo, y contra la vastísima caridad de Él, con la que quiso morir, justo, por los injustos y rogó por quienes lo crucificaron, siendo por todos escuchado, según el apóstol, en señal de respeto ${ }^{126}$. Digo estas cosas para refutar esta idea por completo, pues aunque hubieseis puesto la mano sobre Cristo Señor, toda vez que [la suya] se impone sobre vosotros por la fe que recibisteis en el bautismo, vuestros corazones quedan purificados y sois lavados de todo pecado en su sangre; ¡ cuánto más siendo pecadores! ${ }^{127}$ [§50] Con mansedumbre podéis responder que, aunque algunos pocos de vuestra raza, los príncipes de los sacerdotes y los fariseos de aquel tiempo, que sentían por Él envidia y odio porque a ellos los reprendía más que a los demás, mediante sus ministros entregaron a Cristo y lo acusaron y con sus lenguas lo crucificaron, ello no lo hicieron todos los judíos de su tiempo, porque los oriundos de otras tierras, cuyo número era casi infinito, dispersos por

${ }^{125}$ No hemos sabido documentar el adverbio achileice, acaso relacionado con la fama de astuto y artero de Aquiles. A falta de ninguna otra opción, lo hemos traducido, pues, como 'taimadamente'. Tal vez pudiera querer referirse a aquila, aquilinus.

126 Cf. Díaz de Montalvo, La causa conversa $\S \S 11-12$, o Torquemada, Tratado contra los madianitas $\$ 2.5$, pág. 260: «dicho fundamento es erróneo, porque parece claramente vaciar la fuerza de la pasión de Cristo y restringir su eficacia».

127 Veáse la nota 18 y, además, Cartagena, Defensorium II.4.11; Torquemada, Tratado contra los madianitas §2.6, y OROPESA, Luz para el conocimiento \$39-40. 
todo el mundo a causa de las persecuciones precedentes, no estuvieron presentes allí; por tanto, ni todos pudieron haber acudido al día festivo, por más que fuese un precepto legal, porque la cautividad y otras causas y asuntos excusaban legítimamente su ausencia. [§51] Y no es un impedimento que se lea que vinieron a la festividad «de todas las naciones», porque la palabra 'todas' no tiene aquí un sentido distributivo que equivalga a todos y cada uno de los pertenecientes a una nación, sino que más bien se toma por las naciones de esos individuos, de manera que 'de todas las naciones' significaba aquí 'algunos', vale decir 'algunos hombres piadosos', pero no todos y cada uno de aquellas naciones. [\$52] Además, ni en la ciudad ni en los alrededores podría haberse acogido a una multitud tan grande, ni tampoco los príncipes de los territorios en que estaban cautivos les habrían permitido marcharse así, todos juntos; finalmente, tampoco todas las ciudades, habitantes o peregrinos que llegaron a la festividad dieron su consejo, ayuda o acuerdo, porque eran los más ancianos los que únicamente eran admitidos para deliberar, sobre todo en asuntos arduos, y para este impío sanedrín, tal y como refiere la historia evangélica, se congregaron justamente los sacerdotes y los escribas fariseos y los ancianos; y tampoco todos de entre los fariseos o los ancianos, porque José de Arimatea, que era un discípulo secreto de Jesús, y Nicodemo, que se había llegado de noche a Jesús, estos no tuvieron parte en la decisión de la muerte, sino que se ocuparon de sepultarlo piadosamente. [\$53] A la muchedumbre del pueblo, que lo tenía por profeta, y a la turba numerosa que lo seguía, con las mujeres que plañían y se lamentaban por él, ha de eximírsela de este oprobio, pues por temor de ellos los príncipes citados buscaron con el traidor Judas la ocasión oportuna para ver cómo podían capturarlo sin ellos. [§54] Pero si por unos pocos quieren hacer a todo el linaje judío reo de su muerte, condénese también a toda la estirpe gentil porque Pilatos, gentil, lo sentenció, y sus soldados, gentiles, lo crucificaron, y se burlaron de él ofreciéndole vinagre y diciéndole: «Si eres el rey de los judíos, sálvate a ti mismo». Uno de ellos le abrió el costado con una lanza. [§55] Por lo demás, tras la resurrección y la ascensión a los cielos de nuestro Salvador, predicando los judíos la fe de Cristo por todo el orbe, ¿quién crucificó a Cristo en sus miembros durante más de trescientos años, castigando con diversos tormentos a los apóstoles y otros mártires, por millares que nadie podría contar, y finalmente llevándolos a la muerte, 
sino los emperadores gentiles y sus jueces, cuya cruel ferocidad e inmensa brutalidad la Iglesia de los cristianos hoy contempla asombrada y la condena? ¿Acaso por culpa de estos y de Mahoma, que era de la nación gentil, condenaremos y reprobaremos a la Iglesia de los gentiles, en la que hoy Dios es verdaderamente servido? En absoluto. Más bien al contrario, deberíamos estarle inmensamente agradecidos por haber engrandecido su nombre, de oriente a occidente, entre los gentiles. [§56] ¿Sería una argumentación recta, por el hecho de que uno de los apóstoles fuese un traidor, hacer recaer el crimen de traición sobre todo el colegio apostólico? ¿O, porque uno de los ladrones blasfemó contra Cristo, considerar que el otro, que dirigiéndose a Cristo le dijo: «Señor, acuérdate de mí cuando llegues a tu reino», no fue digno de oír: «En verdad te digo, hoy estarás conmigo en el paraíso»? [\$57] Concluyamos, pues, con el apóstol, que todos pecaron, gentiles y judíos ${ }^{128}$, y que todos tienen necesidad de la gloria de Dios, y que ya no hay diferencias entre judío y griego, y que Dios no hace acepción de personas, sino que cualquiera que invoque el nombre de Dios se salvará.

[§58] Tal vez se responderá: «Es verdad que aquel pecado no recae sobre los descendientes ni pasa a los congéneres en cuanto a la culpa ni en cuanto a la condena de pena eterna, porque, como dice el profeta, 'el alma que peque, morirá; el hijo no cargará con la maldad del padre', etc. ${ }^{129}$; pero en lo tocante a la condena de pena temporal el Señor a veces sí castiga al hijo por el padre, o dicho de otro modo, al padre en el hijo, porque él mismo dijo en Éxodo: 'Yo soy el Señor tu Dios, fuerte y celoso, que castiga la maldad de los padres en los hijos', etc.; [\$59] y no solo a los hijos, nietos y biznietos por los pecados de los padres, sino a veces a los conciudadanos y los compatriotas por los pecados de otros

128 Cf. Cartagena, Defensorium II.3.4, pág. 144: «Omnes itaque tam israelite quam gentiles huic actui interfuerunt»; OROPESA, Luz para el conocimiento §37, pág. 455: «Y en su sacratísima crucifixión estuvieron igualmente todos presentes, tanto los judíos como los gentiles», y DíAz DE Montalvo, La causa conversa $\S 8$;

129 Díaz De Toledo, Instrucción del Relator, págs. 111-112: «y basta lo que dice Dios: anima quae peccauerit, non morietur. Y si la ley de Dios y los derechos no quieren que el padre sea punido por el fijo, ni el fijo por el padre, ni la mujer por el marido, mucho menos deben ser los otros que no tienen que façer en ello, aunque se diga que todos desçienden de un pueblo o de una gente»; también Torquemada, Tratado contra los madianitas \$2.2-7, o BARRIENTOS, Respuesta a una duda, págs. 173-174. 
ciudadanos y compatriotas, y a los congéneres y miembros de una misma tribu por los pecados de otros de su misma raza o tribu, salvo que el Señor quiera liberarlos por una gracia especial, como liberó a Lot del incendio de los sodomitas, o a Noé de la inundación del diluvio. [\$60] Estos crucificadores parece que pidieron esta pena contra sí y sus hijos, diciendo: 'Que sea su sangre sobre nosotros y sobre nuestros hijos', algo que fue después cumplido con las matanzas, el cautiverio y la dispersión a la que los sometieron los romanos por el asesinato de Cristo».

[§61] De todo lo anterior, no obstante, puede desprenderse con nitidez una respuesta para hacer cesar la oportunidad de la discusión. Debéis responder de otro modo, con los santos doctores: que los pecados de los padres se castigan en los hijos con pena temporal si los hijos son émulos de los crímenes de los padres, algo que Dios quiso declarar en la suprema autoridad del Éxodo, diciendo: «Yo soy el Señor», etc. «que castiga la maldad», etc. «de aquellos», y lo deja claro, «que me aborrecen» ${ }^{130}$. [§62] Y puesto que los judíos que hoy se mantienen en su ceguera, aunque no todos son hijos en cuanto a la carne de aquellos que crucificaron a Jesús, son todos sus hijos en cuanto a la imitación del pecado, pues no creen que Jesús sea Cristo y el verdadero Dios, sino un simple hombre mentiroso y blasfemo; realmente, estos lo crucifican todos los días. Es digno y justo que, mientras dure la culpa de su falta de fe, deba durar su pena de miseria y cautiverio. [§63] Pero no es así, por cierto, para vosotros, hermanos míos, que, aunque fueseis hijos de aquellos en cuanto a la carne, no sois imitadores de los crímenes paternos. Antes bien, abandonada la tiniebla de la falta de fe, es necesario que creáis de corazón, para ser justos, y que con la lengua reconozcáis, para salvaros, que la verdadera luz que ilumina a todo hombre que llega a este mundo, esto es, nuestro Señor Jesucristo, Dios y Hombre verdadero, resucitó de entre los muertos por nuestros pecados, por nuestra justificación ${ }^{131}$, con otros dogmas necesarios para la salvación. «¿Qué parte tiene [el fiel]

130 De nuevo Ex. 20,5, citado arriba, en la nota 82. Cf. Díaz de Montalvo, La causa conversa $\S \S 19$ y 23; BARRIENTOS, Respuesta a una duda, pág. 176: «Ansí que visitaría nuestro Señor o puniría los pecados en los fijos solamente que fueren pecadores como ellos».

131 Oropesa, Luz para el conocimiento §51, pág. 764: «Quien, aunque murió por nuestros delitos, sin embargo, resucitó para nuestra justificación, y ya no muere». 
con los infieles, o qué participación-dice el apóstol- hay entre la justicia y la iniquidad, o qué sociedad entre la luz y las tinieblas, o qué consorcio de Cristo con Belial?». Pecan, por tanto, quienes os envuelven en los mismos crímenes con los infieles y prácticamente os hacen partícipes de ellos.

[§64] Aquello de que los neófitos no pueden ser ordenados es pueril ${ }^{132}$. Os lo lanzan como una injuria quienes desconocen la interpretación y significación de la palabra o no quieren atender diligentemente los decretos que hablan de esta materia. Neófito se traduce como 'nuevo' o 'inexperto en la fe', o 'convertido recientemente a la fe', y el apóstol prohíbe que este sea ordenado como tal, porque todavía no está instruido en las cosas que tocan a la fe ni ha sido probado sobre aquellas cosas que convienen a la religión cristiana; ello para evitar que caiga, hinchado por la soberbia, en el juicio y el lazo del diablo. [\$65] «Pues el sacerdote reciente -dice el canon- desconoce la humildad, los modos de las personas o contenerse a sí mismo. No ha ayunado, no ha llorado, no se ha corregido, no ha compartido lo suyo con los pobres. Caen en la arrogancia, que es la condenación del diablo, quienes al instante, y sin ser todavía discípulos, se vuelven maestros. Es una pena que se haga maestro a quien todavía no ha aprendido a ser discípulo». [§66] Y esta prohibición afecta tanto a los neófitos conversos del judaísmo como a los conversos de la gentilidad o el paganismo; es más, los decretos en esta prohibición hablan de forma más expresa de los gentiles que de los judíos, como aquello de que: «Quien ayer estaba en el teatro, que no se siente hoy en la iglesia; quien la víspera estaba en el circo, no oficie hoy sobre el altar; quien hasta hace nada era aficionado a los comediantes, no sea hoy consagrador de vírgenes». Todo esto, sobre todo lo de estar en el teatro o en el circo, o lo de ser aficionado a los comediantes, los espectáculos y las supersticiones, era propio de los gentiles, no de los judíos.

[§67] El canon del Concilio de Nicea dice esto con claridad: «Porque muchas cosas se hacen contra la regla, ya por necesidad o por cualquier otra causa, de tal modo que hombres que recientemente han venido al bautismo espiritual, pasando de una vida gentil a ser catecúmenos o

132 Cf. Cartagena, Defensorium II.4.28; Díaz de Montalvo, La causa conversa §44; Oropesa, Luz para el conocimiento §50, y BARRIENTOS, Respuesta a una duda, págs. 187-188. 
recién instruidos, y enseguida, una vez son bautizados, son llevados al episcopado, parece que rectamente no debería suceder tal cosa. Pues hace falta un tiempo para ser catecúmeno, $\mathrm{y}$ tras el bautismo es necesario ser puesto a prueba un largo periodo»».

[§68] Y también puede entenderse de los neófitos de los judíos aquel decreto del Concilio de Toledo: «Que quienes son judíos o proceden de judíos no puedan desempeñar oficios públicos», aunque para algunos puede entenderse, y correctamente, referido a los judíos y sus sacerdotes, mientras que para otros es referido a los judíos y a los cristianos que en otro tiempo fueron judíos ${ }^{133}$; [§69] sobre los cuales instituyó otro decreto el quinto Concilio Toledano: «Muchos de los judíos, que recientemente han pasado a la fe cristiana, ahora, blasfemando contra Cristo, se sabe que no solo celebran sus ritos judaicos, sino que incluso practican las abominables circuncisiones»; de ellos dice también allí el decreto: «Esta clase de transgresores deben ser traídos al culto de la religión cristiana mediante la corrección de la autoridad pontifical».

[§70] Decir que esta prohibición del apóstol y las sanciones canónicas que hablan de esta materia han de aplicarse a todos los conversos del judaísmo es una interpretación escandalosa, temeraria, que sabe a herejía y que induce al cisma, como puede colegirse con claridad de todo lo sobredicho. [\$71] San Ambrosio afirma lo opuesto, cuando trata de aquellas palabras del apóstol a los Romanos, Al judio primero, también luego al griego: «Nombra primero -dice- al judío, por prerrogativa de los Padres, o bien para ser ensalzado antes, o bien para ser condenado con más severidad», algo que antes de San Ambrosio sancionaba claramente San Clemente, quien, predicando a los judíos la fe de Cristo, como narra la historia eclesiástica, usaba de este orden, concediéndoles esta gracia, y afirmaba que sus ascendientes habían sido amigos de Dios y conmemoraba que su ley era santa y sacratísima ${ }^{134}$. [§72] Y añadía que ellos obtendrían el primer lugar si guar-

133 Torquemada, Tratado contra los madianitas §16; Díaz de Montalvo, La causa conversa §43, y BARRIENTOS, Respuesta a una duda, pág. 171: «Onde es de notar d'este nonbre 'judío' que en dos maneras lo devemos considerar: en una manera son dichos los judíos de nombre et de fecho; en otra manera non de nombre, mas de fecho».

134 Cf. Oropesa, Luz para el conocimiento \$27, pág. 343: «También hay que entender así el testimonio de Clemente en la Historia eclesiástica donde dice que los judíos 
daban los sacramentos de su ley, no negando que la promesa de Dios a Abrahán había sido completada en Cristo, esto es, que Dios prometió que todas las gentes tendrían parte de la herencia de la semilla de Abrahán: «Del fruto de tu vientre pondré sobre tu trono»; y lo que por medio de Isaías confirmó diciendo que una virgen concebiría en su vientre y pariría un hijo al que se daría el nombre de Emmanuel. [§73] Esto lo afirmáis vosotros con sinceridad, esto junto con otros artículos de la fe católica, y no ahora, sino desde hace tiempo, y muchos de vosotros desde el nacimiento profesáis firmemente con la Santa Iglesia Católica y Apostólica, totalmente ignorantes de las cosas de otra ley o secta. Y por tanto esta idoneidad es porque habéis ayunado, porque habéis llorado, porque habéis recibido instrucción, porque habéis sido puestos a prueba, y si ayer o anteayer hubieseis sido convertidos os llamarían neófitos y se os creería o juzgaría comprendidos bajo la regla, el derecho o la ordenación de estos.

[\$74] Consolaos, pues, consolaos, pueblo de Dios, porque, al contrario de lo que estos hombres vanos e ignorantes dicen, la Sagrada Escritura, la fe católica y la Santa Iglesia de Dios no os reputa por viles y humillados, sino que os cree y predica como ilustres y gloriosos: «Ya no sois huépedes y extranjeros, sino ciudadanos de los lugares sagrados y servidores de Dios, edificados sobre los cimientos de los apóstoles y de los profetas, siendo piedra angular el mismo Cristo Jesús, en quien toda edificación se alza bien fundada para ser templo santo en el Señor». [\$75] Y es así que todos los días canta la Iglesia que Simeón, el justo, mientras sostenía en sus brazos a Cristo nuestro Señor, declaró de Él, imbuido por un espíritu profético, que era luz para conocimiento de los gentiles y gloria de su pueblo, Israel. [\$76] Y escuchad a su vez a vuestro Pablo, que os consuela en vuestra pusilanimidad: «¿Es que acaso Dios ha rechazado a su pueblo? En absoluto. Pues yo -dice- también soy israelita, de la semilla de Abrahán, de la tribu de Benjamín. Dios no ha rechazado a su pueblo, al que de antemano conoció» ${ }^{135}$; y más abajo, hablando sobre el mismo pueblo de los judíos: «¿Acaso tropezaron para caer? De ningún

que son buenos, etc., deben ocupar en la Iglesia el primer lugar»; CARTAGEna, Defensorium II.1.8.

135 Cf. Cartagena, Defensorium II.1.1, y Torquemada, Tratado contra los madianitas $\$ 3.2$. 
modo; antes bien con su transgresión vino la salvación a los gentiles, para que los emulasen; y si su delito es la riqueza del mundo y su menoscabo la riqueza de los gentiles, ¡cuánto más lo será su plenitud!»; y añade: «Porque si su reprobación es reconciliación del mundo, ¿qué será su reintegración sino una resurrección de entre los muertos? Pues si las primicias son santas, también la masa; si la raíz es santa, también las ramas. Y si algunas de las ramas fueron desgajadas, tú, siendo acebuche, fuiste injertado en ella y hecho partícipe de la raíz y de la enjundia de la oliva. No te ensoberbezcas contra las ramas, pues si te vanaglorias, no sustentas tú a la raíz, sino la raíz a ti. Dices: las ramas fueron desgajadas para que yo fuera injertado. Bien: por su incredulidad fueron desgajadas, y tú por la fe estás en pie. No te engrías, antes teme; porque, si Dios no perdonó a las ramas naturales, tampoco a ti te perdonará. Considera, pues, la bondad y la severidad de Dios; la severidad para los caídos, para contigo la bondad, si permaneces en la bondad, que de otro modo también tú serás desgajado. Mas ellos, de no perseverar en la incredulidad, serán injertados, que Dios es poderoso como para injertarlos de nuevo; porque, si tú fuiste cortado de un olivo silvestre y contra naturaleza injertado en un olivo legítimo, ¡cuanto más estos, los naturales, podrán ser injertados en el propio olivo!» ${ }^{136}$. [§77] He aquí cuán magníficamente os ensalza y cuán dulcemente os consuela el apóstol: os ensalza magníficamente cuando llama a vuestros padres primicias santas y raíz santa, y a vosotros masa santa y ramos santos; y os consuela dulcemente cuando no dice que la ruina de vuestra estirpe sea universal, lo cual afectaría todos los del linaje y a los que derivasen de él, porque no fue irreparable e inútil, sino intrínsecamente reparable y útil para el mundo ${ }^{137}$. Esto es lo que el apóstol escribió: yo solo lo transcribo para que tengáis algo con que poder responder a los calumniadores. [§78] No busquéis la gloria en la carne ni en la nobleza del linaje carnal, porque el mismo apóstol dice a menudo: «Quien se vanaglorie, que se vanaglorie en el Señor»; y «Quede lejos de mí gloriarme, si no es en la cruz de nuestro Señor Jesucrito»; y en otro lugar: «Gustosamente me vanagloriaré de mis debilidades, para que la

136 Sobre este passaje, véase la introducción; $c f$. también TorquEMADA, Tratado contra los madianitas §13.5-11.

137 Cf. Torquemada, Tratado contra los madianitas §13.5, pág. 303: «la caída de los judíos no es irreparable como lo fue la caída de los demonios, más aún, es reparable». 
fuerza de Cristo habite en mí, porque, por Cristo, me complazco en mis debilidades, en las ofensas, en las necesidades, en las persecuciones, en las dificultades».

[§79] Veis, por tanto, queridísimos, cómo toda la Santa Escritura, con el ejemplo de Cristo y de los santos os invita tan eficazmente a la paciencia y tan dulcemente os consuela en las tribulaciones. Sobre esto vuestro obispo Santiago ofrece una apretada síntesis, dirigiéndose a vosotros como si os hablase en una charla en su canónica: «Tomad, hermanos, como ejemplo de abandono del mal y de longanimidad, de entereza y de paciencia, a los profetas que hablaron en nombre del Señor. No por otra razón reverenciamos a los que sobrellevaron el sufrimiento. Habéis oído hablar de Job y sabéis qué fin le concedió el Señor, porque el Señor es misericordioso y compasivo».

[§80] Volveos, pues, hacia Él con todo vuestro corazón y toda vuestra alma, e invocad su nombre en Jesucristo, su único Hijo y Señor nuestro, en quien no valen en nada la circuncisión ni el prepucio, sino la nueva criatura ${ }^{138}$. Reformaos en el espíritu de vuestra mente, despojando al hombre viejo con todas su obras y vistiéndoos del hombre nuevo, creado de acuerdo con Dios en la justicia y la santidad de la verdad, diciendo con vuestro Isaías: «El antiguo error ha desaparecido; tú conservarás la paz; la paz, porque en ti, Señor, hemos esperado». Si así lo hacéis, el Señor os escuchará y se apiadará de vosotros. El Señor estará a vuestro lado, convertirá vuestro llanto en gozo, rasgará vuestro saco y os rodeará de alegría.

[§81] Os escribo estas cosas, hermanos, no en un estilo sublime ni con las palabras seductoras de la sabiduría humana, sino con compasión de ánimo, usando del lenguaje simple de la Sagrada Escritura, para que tengáis esperanza por medio de la paciencia y el consuelo de las Escrituras. Dios os dé paciencia y solaz, un mismo sentir, y aplaste velozmente a Satanás [bajo] vuestros [pies]. Que la gracia de nuestro Señor Jesucristo sea con vosotros. Amén.

138 Cartagena, Defensorium II.4.15, pág. 198: «Quid ergo est dicere aliquid non valere circumcisionem nec preputium, nisi quod nulla differentia ex hoc assumi potest?», y Oropesa, Luz para el conocimiento §37, págs. 476-477. 
[§82] CONCLUSIONES O SENTENCIAS QUE EN ALABANZA Y GLORIA DE NUESTRO SEÑOR JESUCRISTO Y DE SU SANTISIMA MADRE LA VIRGEN MARÍA Y PARA CONSOLACIÓN VUESTRA Y CONFUTACIÓN DE LOS ADVERSARIOS PUEDEN EXTRAERSE COMO COROLARIO O INCIDENTALMENTE DE LAS COSAS ANTEDICHAS. SON LAS QUE SIGUEN.

Primera conclusión. Decir que Cristo nuestro Señor y su santísima madre la Virgen María no eran del linaje de los judíos es herético, y quien esto asevera pertinazmente es un hereje ${ }^{139}$.

Segunda conclusión. Decir que todos los descendientes de judíos son innobles o de linaje indigno es herético; quien esto asevera pertinazmente es un hereje.

Tercera conclusión. Decir que todos los conversos de la circuncisión se encuentran en peligro de condenación o que no son hábiles para la gracia y la gloria es herético, y quien esto asevera pertinazmente es un hereje.

Cuarta conclusión. Decir que todos los tales no son merecedores de dignidades eclesiásticas y temporales, o inhábiles para recibirlas, es escandaloso, temerario y, si esto se concluye a partir de aquellas premisas heréticas, es también herético; quien esto asevera pertinazmente es un hereje.

Quinta conclusión. Decir que mediante la conversión a la fe de Cristo hay distinción entre judío y gentil es herético, y quien esto asevera pertinazmente es un hereje, y quien por elección desea esta distinción, o de facto la procura con denuedo es cismático.

Sexta conclusión. Quien odia a los conversos a Cristo porque son del linaje de los judíos se sitúa fuera de la caridad y en peligro de condenarse.

Séptima conclusión. Quien los desprecia porque son de aquel linaje desprecia a Cristo y realmente se erige en enemigo suyo ${ }^{140}$.

139 Cf. Torquemada, Tratado contra los madianitas \$4.4, pág. 270: «Como quiera que María santísima era judía, descendiente de judíos, si la raza judía hubiera sido condenada, según afirman estos blasfemos, sería necesario que ellos dijeran que la misma gloriosísima y santísima Virgen nació de una raza condenada, infiel y adúltera».

140 Cf. Torquemada, Tratado contra los madianitas \$14.3, pág. 311: «De ahí que despreciar a algún fiel, porque desciende de la raza judía, parece ser desprecio y vilipendio de Cristo». 
Incitativo [?]. Los príncipes eclesiásticos y temporales han de proceder, de acuerdo con ambos derechos y con las normas, contra los citados herejes, hombres inicuos y blasfemos, y castigarlos con la condena que corresponda, porque pecarán mortalmente si no lo hacen.

Recibido: 20/01/2021

Aceptado: 25/07/2021 